\title{
13. MID-CRETACEOUS CALCAREOUS NANNOPLANKTON FROM THE CENTRAL PACIFIC: IMPLICATIONS FOR PALEOCEANOGRAPHY ${ }^{1}$
}

\author{
Peter H. Roth, Department of Geology and Geophysics, University of Utah, Salt Lake City, Utah
}

\begin{abstract}
Moderately well-preserved calcareous-nannoplankton assemblages from the western Mid-Pacific Mountains and Hess Rise reflect paleoceanographic conditions during the middle Cretaceous. Sediments enriched in detrital organic carbon from the Barremian (NC6) at Deep Sea Drilling Project Site 463 contain impoverished assemblages indicative of strong dissolution and adverse water conditions (e.g., high turbidity, fresh-water inflow from islands). A steady increase in the nannolith genera Zygodiscus and Biscutum and in overall diversity throughout the middle Cretaceous at Site 463 is indicative of a change to more favorable surface-water conditions, but not of highly nutrient-rich surface waters. Coccolith assemblages at Site 464 are poorly preserved and thus marginal at best for quantitative investigations. Assemblages with a high relative abundance of coccolith species indicative of high nutrient concentrations occur on southern Hess Rise (Sites 465 and 466). Organic carbon of marine origin is commonly preserved at these sites, supporting the inferences based on coccolith assemblages. High productivity in conjunction with warm deep waters of low oxygen content seems sufficient to explain the occurrence of "black shales" in the Pacific. Injection of saline and oxygenpoor Atlantic deep water seems unlikely.
\end{abstract}

\section{INTRODUCTION}

The "middle Cretaceous anoxic event" has received much attention in the last five years. Speculations still outweigh solid information, and a consensus has not yet been achieved (see Arthur, 1979, and Berger, 1979, for reviews). This paper is an attempt to provide information based on the abundance and preservation of calcareous nannofossils, setting constraints on further speculations about tropical Pacific paleoceanography during the middle Cretaceous. A detailed discussion on the "black shale problem" and integration of sedimentological, geochemical and micropaleontological information has been attempted by Roth and Bowdler (in press). This paper treats sedimentological, geochemical, and paleoceanographic information as it applies to the preservation and distribution of calcareous nannofossils.

Equatorial deep-sea sections of middle Cretaceous age have not yet been recovered and are not likely to be cored in the Atlantic and Indian oceans, because of paleogeographic and tectonic constraints. The Pacific is thus our only hope to fill this gap. Problems of strong diagenetic effects and poor recovery have impaired an effort to study nannoliths from Pacific sections so far (Roth, 1973). However, more-complete sections recovered from the Mid-Pacific Mountains and Hess Rise during DSDP Leg 62 have provided nannolith assemblages that are well enough preserved to make a first attempt at a study of equatorial nannolith preservation and ecology in the middle Cretaceous.

\footnotetext{
${ }^{1}$ Initial Reports of the Deep Sea Drilling Project, Volume 62
}

\section{ECOLOGY OF MIDDLE CRETACEOUS CALCAREOUS NANNOFOSSILS}

If one assumes that Recent calcareous nannoplankton are an adequate analog for Cretaceous calcareous nannoplankton, then these organisms were largely restricted to the photic zone, i.e., the upper 50 to 200 meters of the water column. At present (a cryogenic time with cold polar seas and warm tropical waters) gradients of species diversity and nannofloral distribution patterns are largely controlled by surface-water temperature. Differences in salinity, nutrients and neritic effects are only minor factors affecting coccolithophorid distribution in the water column (Honjo, 1977). Coccolith distribution in sediments is strongly affected by carbonate dissolution at depth (McIntyre and McIntyre, 1971; Schneiderman, 1973, 1977; Roth and Berger, 1975; Roth and Coulbourn, in press). Uncertainty about the physical and chemical parameters in the ancient oceans increases with geologic age. Whereas latitude seems to have exerted the dominant control on the distribution of coccolith assemblages during the Cenozoic (Haq and Lohmann, 1976) and Late Cretaceous (H. Thierstein, pers. comm., 1979), its influence was less pronounced in the middle Cretaceous and earlier times (Roth and Bowdler, in press). This is expected for acryogenic times when global temperature gradients were reduced. Coccolith remains are greatly altered by preferential dissolution on the sea floor, which makes reconstruction of the original distribution patterns difficult. Preservation of the calcitic nannoliths (coccoliths and other nannofossils of unknown biologic affinity) is variable during the geologic history of the oceans. Dissolution of nannoliths at depth is most severe during times of great undersaturation of $\mathrm{CaCO}_{3}$ in the deep 
oceans. Such times are characterized by a shallow calcite-compensation depth, resulting in sediments of low calcium carbonate content. Recent compilations of sediment distribution patterns by van Andel (1975) and Thierstein (1979) show that the CCD was shallower by about $1 \mathrm{~km}$ during the middle Cretaceous than during the early and latest Cretaceous. In addition, the number of sedimentary sections decreases with age, because of the age distribution of the sea floor. These restrictions allow only large-scale distribution patterns and temporal changes of nannolith patterns to be described at the present time. A first attempt to explain biogeographic patterns of the middle Cretaceous nannoliths in Atlantic and Indian ocean sediments (Roth and Bowdler, in press; Roth and Krumbach, in prep.) has shown the following:

1) Nannolith assemblages show minor change with latitude in a wide tropical belt (about $40^{\circ} \mathrm{N}$ to $40^{\circ} \mathrm{S}$ ).

2) Bipolar high latitude assemblages of largely similar composition occurred at higher latitude.

3) The dense sample distribution available in the subtropical North Atlantic demonstrates pronounced eastwest gradients in the abundance of the dominant species. This is explained by upwelling in the eastern North Atlantic. Studies of the organic geochemistry (Tissot et al., 1979) and of palynomorph distribution (Habib, 1979) corroborate this finding.

4) Only high- and mid-latitude assemblages in the South Atlantic and in British epicontinental deposits show great fluctuations in the abundances of many nannolith species, in some cases almost monospecific or "bloom" assemblages.

5) Nannoconids once thought to be restricted to the Tethys and to more-neritic environments (Berger and Roth, 1975) are found at latitudes as high as $55^{\circ}$ and on oceanic plateaus (Roth, 1973, and this paper).

\section{SAMPLES AND METHODS}

A total of 130 samples was taken from middle Cretaceous cores recovered during Leg 62 . Light-microscope slides were prepared using standard techniques, and all samples were checked for abundance, diversity, and preservation according to the semiquantitative scale of calcareous-nannoplankton assemblages. At least 300 specimens were counted in each of the 32 well-preserved samples. All samples are listed in Table 1.

\section{BIOGEOCHRONOLOGY}

The middle Cretaceous as defined in this paper embraces the time between about 115 and 90 m.y. ago. The four oceanic stages Canaveralian, Magellanian, Atlantian, and Tenerifian are included. They correlate more or less with the classical European stages Barremian, Aptian, Albian, Cenomanian and lower Turonian (Roth, 1978). The nannoplankton zones used in this report and the time scale are identical to the ones proposed in Roth (1978); it is preferred over van Hinte's (1976) time scale for the reasons discussed in the former paper. In addition, it results in more reasonable sedimentation rates for middle Cretaceous sediments recovered during Leg 62. The correlation of magnetostratigraphic units with the biostratigraphic scale for Site 463 differs somewhat from previous results (Roth, 1978) in that the "mixed
Table 1. Samples used in this study.

\begin{tabular}{|c|c|c|c|c|}
\hline Sample & $\begin{array}{l}\text { Studied } \\
\text { in Detail }\end{array}$ & Etching & $\begin{array}{l}\text { Over- } \\
\text { growth }\end{array}$ & $\begin{array}{c}\text { Age } \\
\text { (NC zone) }\end{array}$ \\
\hline $463-48-2,10 \mathrm{~cm}$ & * & 1 & 2 & 11 \\
\hline $463-40, \mathrm{CC}$ & & 2 & 3 & 11 \\
\hline $463-43-2,10$ & & 2 & 3 & 11 \\
\hline $463-43, \mathrm{CC}$ & * & 2 & 2 & 11 \\
\hline $463-44-1,78$ & & 2 & 2 & 11 \\
\hline $463-46-1,57$ & * & 1 & 2 & 11 \\
\hline $463-48-1,75$ & * & 1 & 2 & 11 \\
\hline $463-48-1,140$ & $*$ & 2 & 2 & 11 \\
\hline $463-48-2,95$ & $*$ & 2 & 2 & 11 \\
\hline $463-50-1,46$ & & 2 & 3 & 10 \\
\hline $463-52, \mathrm{CC}$ & * & 2 & 2 & 10 \\
\hline $463-53, \mathrm{CC}$ & & 3 & 3 & 8 \\
\hline $463-54, \mathrm{CC}$ & * & 2 & 2 & 8 \\
\hline $463-55-1,32$ & & 2 & 3 & 8 \\
\hline $463-56-1,21$ & & 2 & 3 & 7 \\
\hline $463-56-1,97$ & * & 2 & 2 & 7 \\
\hline $463-57-2,12$ & & 2 & 3 & 7 \\
\hline $463-57-2,15$ & & 2 & 3 & 7 \\
\hline $463-58-2,15$ & & 2 & 3 & 7 \\
\hline $463-58-2,55$ & & 2 & 3 & 7 \\
\hline $463-59-1,42$ & & 2 & 3 & 7 \\
\hline $463-59-1,64$ & & 2 & 3 & 7 \\
\hline $463-60-2,26$ & & 2 & 3 & 7 \\
\hline $463-60-2,135$ & & 2 & 3 & 7 \\
\hline $463-60-4,122$ & & 2 & 3 & 7 \\
\hline $463-61-1,80$ & & 2 & 3 & 7 \\
\hline $463-62-1,85$ & & 2 & 3 & 7 \\
\hline $463-62-1,114$ & & 2 & 3 & 7 \\
\hline $463-62-2,73$ & & 2 & 3 & 7 \\
\hline $463-62-2,130$ & & 2 & 3 & 7 \\
\hline $463-63-1,109$ & & 2 & 3 & 7 \\
\hline $463-63-2,135$ & & 2 & 3 & 7 \\
\hline $463-64-1,117$ & & 2 & 3 & 6 \\
\hline $463-64-2,112$ & & 2 & 3 & 6 \\
\hline $463-65-2,106$ & & 2 & 3 & 6 \\
\hline $463-66-1,37$ & & 2 & 3 & 6 \\
\hline $463-66-2,58$ & & 2 & 3 & 6 \\
\hline $463-67-1,135$ & & 2 & 3 & 6 \\
\hline $463-67-2,106$ & & 2 & 3 & 6 \\
\hline $463-69-1,105$ & * & 2 & 3 & 6 \\
\hline $463-69-1,125$ & & 2 & 3 & 6 \\
\hline $463-69-2,93$ & & 2 & 3 & 6 \\
\hline $463-69-2,148$ & & 2 & 3 & 6 \\
\hline $463-70-1,50$ & & 2 & 3 & 6 \\
\hline $463-70-1,130$ & & 2 & 3 & 6 \\
\hline $463-70-2,120$ & & 2 & 3 & 6 \\
\hline $463-70-3,63$ & & 2 & 3 & 6 \\
\hline $463-70-4,41$ & & 2 & 3 & 6 \\
\hline $463-70-4,75$ & & 2 & 3 & 6 \\
\hline $463-70-5,6$ & & 3 & 2 & 6 \\
\hline $463-70-5,23$ & & 3 & 2 & 6 \\
\hline $463-70-5,27$ & & 3 & 2 & 6 \\
\hline $463-70-5,57$ & & 3 & 2 & 6 \\
\hline $463-70-5,73$ & * & 3 & 2 & 6 \\
\hline $463-70-5,83$ & $*$ & 3 & 2 & 6 \\
\hline $463-70-5,85$ & & & B & 6 \\
\hline $463-70-5,89.5$ & & 3 & 2 & 6 \\
\hline $463-70-5,94$ & & 3 & 2 & 6 \\
\hline $463-70-5,125$ & & 3 & 2 & 6 \\
\hline $463-70-5,134$ & & & B & 6 \\
\hline $463-70-5,135$ & & & B & 6 \\
\hline $463-70-5,140.5$ & & & VB & 6 \\
\hline $463-70-5,141$ & & & VB & 6 \\
\hline $463-70-6,20$ & & & B & 6 \\
\hline $463-70-6,38$ & & & VB & 6 \\
\hline $463-70-6,144$ & & & B & 6 \\
\hline $463-71-1,91$ & & 3 & 3 & 6 \\
\hline $463-71-2,104$ & & 3 & 3 & 6 \\
\hline $463-71-3,45$ & & 3 & 3 & 6 \\
\hline
\end{tabular}


Table 1. (Continued).

\begin{tabular}{|c|c|c|c|c|}
\hline Sample & $\begin{array}{l}\text { Studied } \\
\text { in Detail }\end{array}$ & Etching & $\begin{array}{l}\text { Over- } \\
\text { growth }\end{array}$ & $\begin{array}{c}\text { Age } \\
\text { (NC zone) }\end{array}$ \\
\hline $463-71-4,97$ & & 3 & 3 & 6 \\
\hline $463-72-1,144$ & * & 2 & 2 & 6 \\
\hline $463-72-2,54$ & & & 3 & 6 \\
\hline $463-72-4,86$ & & & 3 & 6 \\
\hline $463-73-1,65$ & & & 3 & 6 \\
\hline $463-73-2,54$ & & & 3 & 6 \\
\hline $463-73-3,72$ & & & 3 & 6 \\
\hline $463-74-1,104$ & & & 3 & 6 \\
\hline $463-75-1,30$ & & & 3 & 6 \\
\hline $463-76-1,23$ & & & 3 & 6 \\
\hline $463-77-1,80$ & & & 3 & 6 \\
\hline $463-78-1,120$ & & & 3 & 6 \\
\hline $463-79-1,76$ & & & B & 5 \\
\hline $463-80-1,18$ & & & B & 5 \\
\hline $463-82-1,56$ & & & 3 & 5 \\
\hline $463-83-1,88$ & & & 3 & 5 \\
\hline $463-84-1,128$ & & & 3 & 5 \\
\hline $463-86-1,99$ & & & 3 & 5 \\
\hline $463-87-1,50$ & & & 3 & 5 \\
\hline $463-88-1,20$ & & & 3 & 5 \\
\hline $463-89-1,55$ & & & B & 5 \\
\hline $463-90-1,12$ & & & VB & 5 \\
\hline $463-91, C C$ & & & 3 & 5 \\
\hline $464-11-1,80$ & & 3 & 3 & \\
\hline $464-12-1,144$ & & 3 & 3 & \\
\hline $464-14-1,7$ & * & 3 & 1 & 11 \\
\hline $464-17, \mathrm{CC}$ & * & 2 & 2 & 10 \\
\hline $464-19, \mathrm{CC}$ & & 3 & 3 & 10 \\
\hline $464-21-1,41$ & & 3 & 3 & 10 \\
\hline $464-23-1,16$ & & 3 & 3 & 10 \\
\hline $464-24, C C$ & & 2 & 2 & 10 \\
\hline $464-25-1,90$ & * & 2 & 3 & 8 \\
\hline $464-26-1,5$ & & 2 & 3 & 8 \\
\hline $464-26-1,70$ & * & 2 & 3 & 8 \\
\hline $464-27-1,5$ & & 3 & 3 & $8-7$ \\
\hline $464-29-1,45$ & & 3 & 3 & $?$ \\
\hline $465 \mathrm{~A}-26-1,15$ & & 3 & 3 & 11 \\
\hline $465 \mathrm{~A}-27-1,95$ & & 3 & 3 & 11 \\
\hline $465 \mathrm{~A}-27, \mathrm{CC}$ & * & 2 & 2 & 11 \\
\hline $465 \mathrm{~A}-28-1,38$ & * & 2 & 2 & 11 \\
\hline $465 \mathrm{~A}-29-1,133$ & * & 1 & 2 & 10 \\
\hline $465 \mathrm{~A}-30-1,24$ & * & 1 & 2 & 10 \\
\hline $465 \mathrm{~A}-31-1,19$ & & 2 & 2 & 10 \\
\hline $465 \mathrm{~A}-33-2,31$ & & 2 & 3 & 10 \\
\hline $465 A-34-1,15$ & & 2 & 2 & 10 \\
\hline $465 \mathrm{~A}-36-1,63$ & * & 2 & 2 & 10 \\
\hline $465 \mathrm{~A}-37-1,60$ & * & 2 & 2 & 10 \\
\hline $465 \mathrm{~A}-38-2,12$ & & 3 & 3 & 10 \\
\hline $465 \mathrm{~A}-39-1,68$ & * & 2 & 2 & 10 \\
\hline $465 \mathrm{~A}-40-1,96$ & & 2 & 3 & 10 \\
\hline $466-29-1,25$ & * & 1 & 2 & 10 \\
\hline $466-30-1,65$ & $*$ & 2 & 2 & 10 \\
\hline $466-31-1,15$ & * & 2 & 2 & 10 \\
\hline $466-35-1,25$ & & 2 & 2 & 10 \\
\hline $466-35-1,81$ & * & 2 & 2 & 10 \\
\hline
\end{tabular}

zone at Site 263"' seems somewhat younger in its type locality (late Albian, NC10, instead of middle Albian, NC8), and M-0 is also slightly older at Site 463 than one would expect from results of investigation in the Atlantic (Sites 417 and 418).

Biogeochronology is summarized in Figure 1.

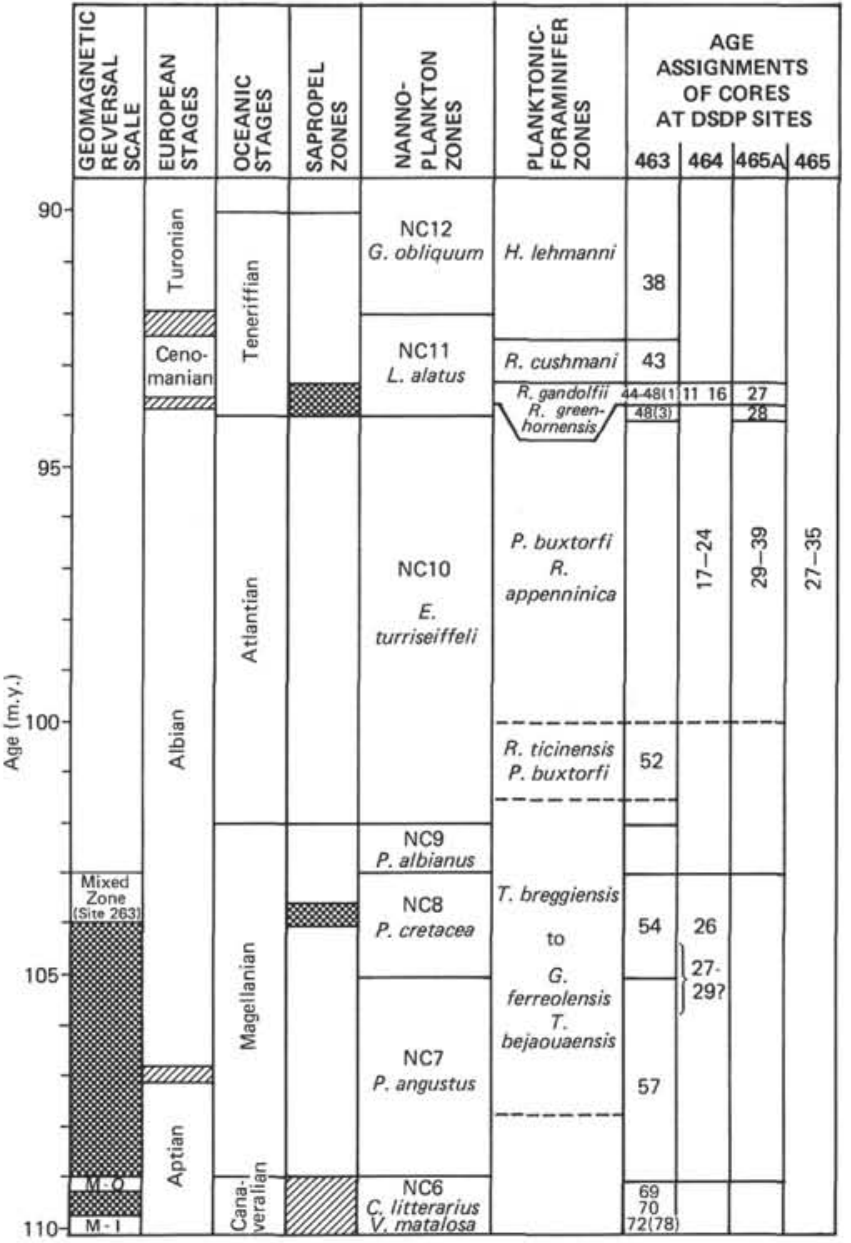

Figure 1. Biogeochronology, radiometric ages, magnetostratigraphy, "sapropel zones," and age assignments for mid-Cretaceous cores. Planktonic foraminifer zone assignments after Boersma (this volume).

\section{LOCATION, GEOGRAPHIC POSITION, AND DEPTH OF SITES IN THE MIDDLE CRETACEOUS}

Site 463 is in the eastern Mid-Pacific Mountains; Site 464 is on Northern Hess Rise; and Sites 465 and 466 are on Southern Hess Rise. Reconstruction of the paleopositions of Leg 62 sites was accomplished by use of poles of rotation and rotation rates proposed by Lancelot and Larson (1975); they are summarized in Table 2.

Reconstruction of original water depths at Pacific drill sites during the middle Cretaceous poses problems (Fig. 2). If the sites are simply "back-tracked"' using the ridge-subsidence curve of Parsons and Sclater (1977), three of the four sites $(463,465$, and 466$)$ would be several hundred meters above sea level before 100 m.y. ago. This exceeds the generally acceptable margin of error for the back-tracking method (200-300 m; Berger and Winterer, 1974). The oldest sediments recovered at Site 463 indicate depths of deposition of 500 meters or less. Simple back-tracking of Site 463 assuming a basement age of $130 \mathrm{~m} . \mathrm{y}$. would place it about 1000 meters 
Table 2. Geographic position and water depth of Leg 62 sites.

\begin{tabular}{|c|c|c|c|c|c|c|c|c|c|c|c|c|}
\hline \multirow[b]{2}{*}{ Site } & \multicolumn{3}{|c|}{ Present } & \multicolumn{3}{|c|}{100 m.y. Ago } & \multicolumn{3}{|c|}{110 m.y. Ago } & \multicolumn{3}{|c|}{125 m.y. Ago } \\
\hline & Lat. & Long. & $\begin{array}{c}\text { Depth } \\
(\mathrm{km})\end{array}$ & Lat. & Long. & $\begin{array}{c}\text { Depth } \\
(\mathrm{km})\end{array}$ & Lat. & Long. & $\begin{array}{c}\text { Depth } \\
(\mathrm{km})\end{array}$ & Lat. & Long. & $\begin{array}{l}\text { Depth } \\
(\mathrm{km})\end{array}$ \\
\hline 463 & $21.3^{\circ} \mathrm{N}$ & $174.6^{\circ} \mathrm{E}$ & 2.4 & $16.3^{\circ} \mathrm{S}$ & $150.7^{\circ} \mathrm{E}$ & $0.5-1$ & $20.9^{\circ} \mathrm{S}$ & $146.0^{\circ} \mathrm{E}$ & 0.5 & $27.3^{\circ} \mathrm{S}$ & $138.0^{\circ} \mathrm{E}$ & 0 \\
\hline 464 & $39.9^{\circ} \mathrm{N}$ & $173.9^{\circ} \mathrm{E}$ & 4.6 & $2.0^{\circ} \mathrm{N}$ & $153.9^{\circ} \mathrm{E}$ & 2.5 & $2.9^{\circ} \mathrm{S}$ & $150.4^{\circ} \mathrm{E}$ & - & - & - & - \\
\hline 465 & $33.8^{\circ} \mathrm{N}$ & $179.3^{\circ} \mathrm{E}$ & 2.2 & $2.9^{\circ} \mathrm{S}$ & $148.7^{\circ} \mathrm{E}$ & 0.7 & $7.5^{\circ} \mathrm{S}$ & $141.1^{\circ} \mathrm{E}$ & - & - & - & - \\
\hline 466 & $34.2^{\circ} \mathrm{N}$ & $179.3^{\circ} \mathrm{E}$ & 2.7 & $2.9^{\circ} \mathrm{S}$ & $148.7^{\circ} \mathrm{E}$ & 1.2 & $7.5^{\circ} \mathrm{S}$ & $145.0^{\circ}$ & - & - & - & - \\
\hline
\end{tabular}

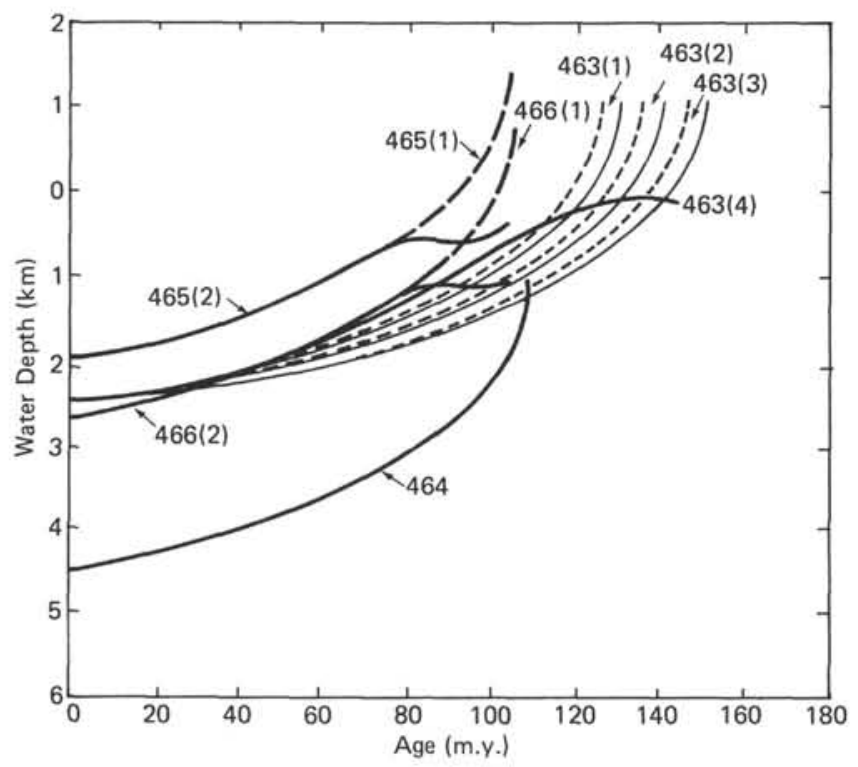

Figure 2. Reconstruction of the paleodepths for Leg 62 sites, using the lithospheric-subsidence curve by Parsons and Sclater (1977). Thin solid lines represent tracks of sea floor without sediment-loading corrections; short dashes are tracks with sediment-loading corrections; long dashes stand for southern Hess Rise tracks without assuming tectonic uplift during the Late Cretaceous; and thick solid lines are the preferred tracks. The number symbols next to the tracks mean the following: 463 (1) basement age of 130 m.y.; 463 (2) basement age of 140 m.y.; 463 (3) basement age of 150 m.y.; 463C (4) starts at sea level, and continued volcanic buildup and uplifting largely compensate for subsidence of the site during the Early Cretaceous; Site 464, normal subsidence curve; 466 (1), 465 (1) track without assuming tectonic uplift of southern Hess Rise; 465 (2), 466 (2) initial normal subsidence, tectonic uplift in the Late Cretaceous.

above sea level. Therefore, a mechanism to explain this discrepancy is necessary. A maximum sea-level rise of 300 meters due to rapid spreading in the middle Cretaceous (Hays and Pittman, 1973) could contribute to increased water depth, but is insufficient alone. Slower subsidence during the early Cretaceous must be invoked to obtain a reasonable sea-floor depth for Site 463 in the middle Cretaceous (Fig. 2).

The following two mechanisms could explain slow subsidence and would result in a reasonable depth of deposition for Site 463 during the later part of the early and middle Cretaceous: (1) Site 463 could be resting on old (140-150 m.y.) sea floor that had subsided to a depth of 0.5 to $1.0 \mathrm{~km}$ by the beginning of the middle Cretaceous; (2) sea-floor subsidence was counterbalanced by thermal uplifting associated with widespread volcanism during the early Cretaceous; once this thermal activity stopped, rapid subsidence took place; (3) post-mid-Cretaceous uplift. Magnetic anomalies (M-25) on the sea floor to the northeast of the site suggest an age of latest Jurassic. Extrapolation of basal sediment ages on the volcanic basement, expected to lie about 100 meters below the oldest sediments recovered, range from 115 m.y. to 130 m.y., depending on sedimentation rates. This volcanic basement could well be a younger edifice sitting on older sea floor. However, Site 463 is too shallow if we assume a late Jurassic to early Cretaceous basement age and subsidence along the standard age/depth curve of Parson and Sclater (1977) (Fig. 1). Preservation and composition of middle Cretaceous coccolith assemblages would be most compatible with a depth of 0.5 to $1.0 \mathrm{~km}$ during that time. The depositional history of Site $\mathbf{4 6 3}$ does not record drastic postmid-Cretaceous tectonic uplifting. Therefore, reduced lithospheric subsidence due to thermal processes during the late Jurassic to early Cretaceous (hypothesis 2 above) best explains the tectonic history of Site 463. Of the Hess Rise sites, 464 does not seem to pose any problems as far as back-tracking is concerned. For Sites 465 and 466, uplift in the late Cretaceous seems necessary to obtain reasonable paleodepths for the middle Cretaceous, consistent with nannoplankton and benthicforaminifer information.

\section{SEDIMENTARY FACIES OF THE DRILL CORES}

A simplified reconstruction of the middle Cretaceous sedimentary columns recovered at each drill site is shown in Figures 3 to 6. Lithology, calcium carbonate, organic carbon (determined at the University of Oslo under the supervision of J. Thiede), preservation of calcareous nannoplankton, sedimentation rates using conservative age assignments based on calcareous nannoplankton and the time-scale on Figure 1, are shown for each site.

At Site 463, the oldest sedimentary rocks (Cores 72-92) consist of interbedded clastic and pelagic limestones of white, gray, and greenish-gray color, with dark-gray cherts, turbidites and debris flows; most sediments are largely burrowed, indicating the presence of at least some dissolved oxygen in the original bottom waters. Calcium-carbonate contents are variable (3$90 \%)$. Organic-carbon contents are generally low $(0.1-$ $0.2 \%$ ), with the exception of the two uppermost cores $(72,73)$, where values of 0.6 to $1.4 \%$ are found. The overlying gray to greenish-gray tuffaceous and carbonaceous limestones with cherts are partly laminated and 


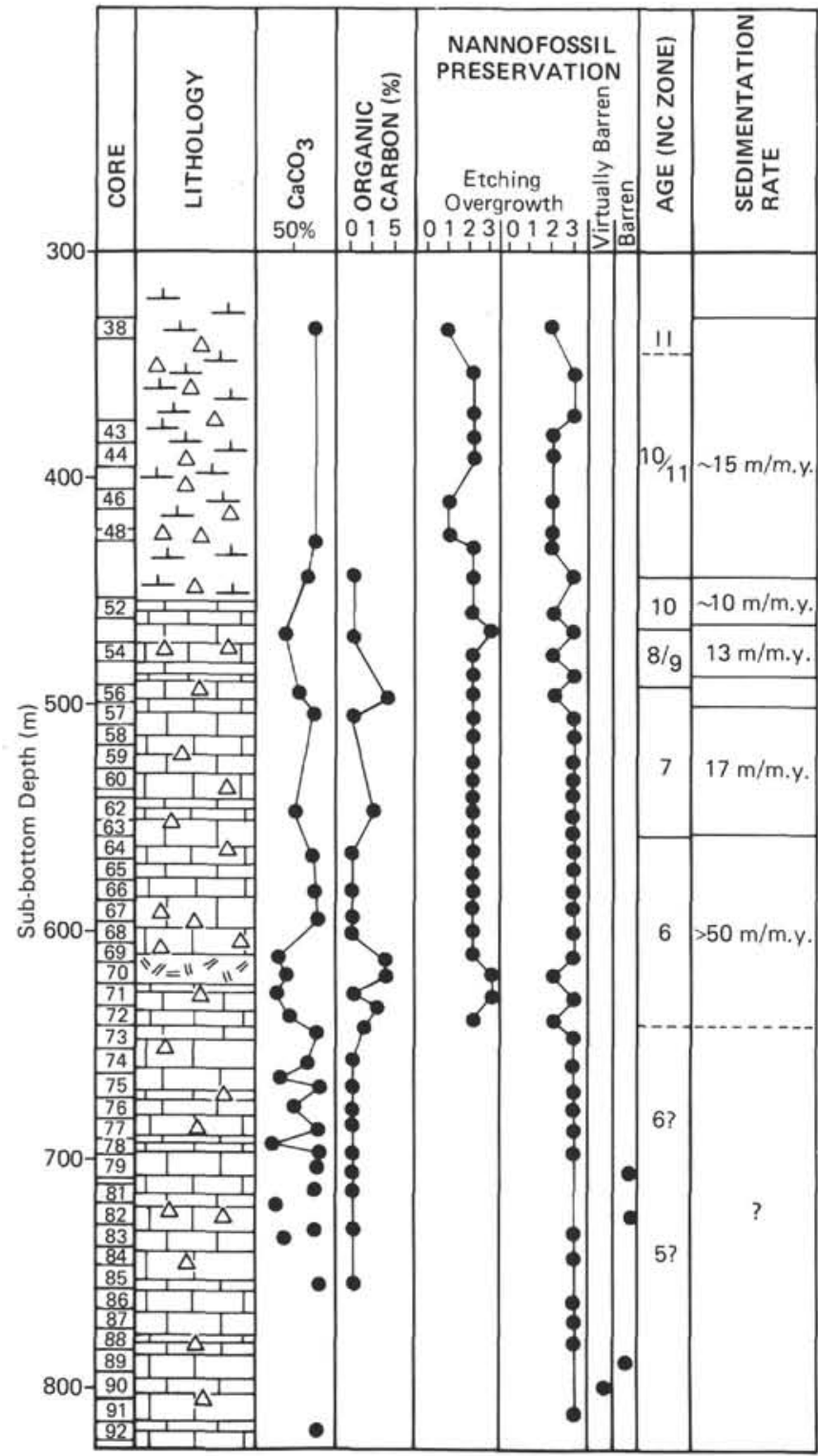

Figure 3. Mid-Cretaceous section at Site 463: lithology, geochemistry, nannolith preservation, and linear sediment-accumulation rates.

partly burrowed (Cores 67-71), indicative of low or fluctuating bottom-water oxygen content. They show low calcium-carbonate contents $(15-30 \%$, with a few extremes of $1.7 \%$ to $76 \%$ and $87 \%$ ), and high organiccarbon contents (maximum $10.6 \%$, many measurements between 2.3 and $4.7 \%$ ). Smear slides show a preponderance of black, coal-like organic matter, suggesting a largely terrestrial source for the organic carbon (see also Dean et al., 1979).

The middle part of the mid-Cretaceous section at Site 463 (Cores 52-66) consists of multicolored limestones and cherts (various shades of white, greenish-gray, green, pink, and brown), indicating a change to moreoxidizing conditions. Calcium-carbonate contents are high, generally above $50 \%$, and as high as $100 \%$. Intervals of high organic-carbon content are found in Cores

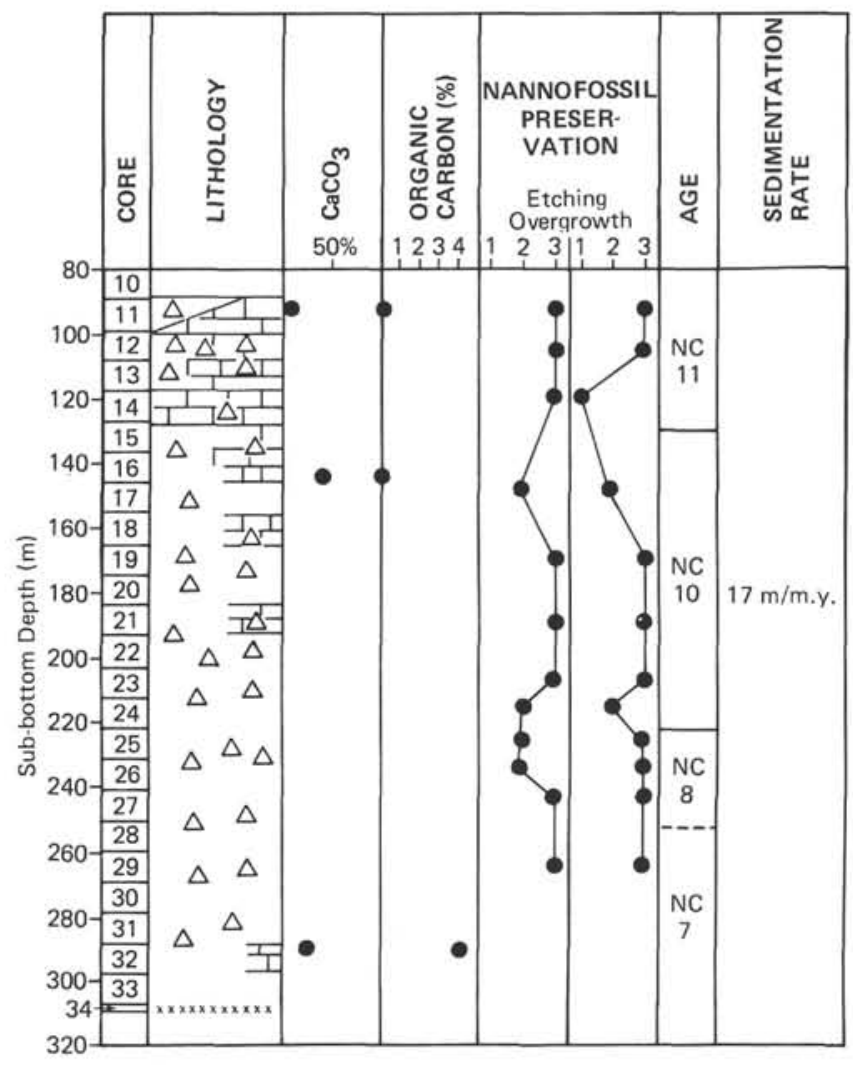

Figure 4. Mid-Cretaceous section at Site 464: lithology geochemistry, nannolith preservation, and linear sediment-accumulation rate.

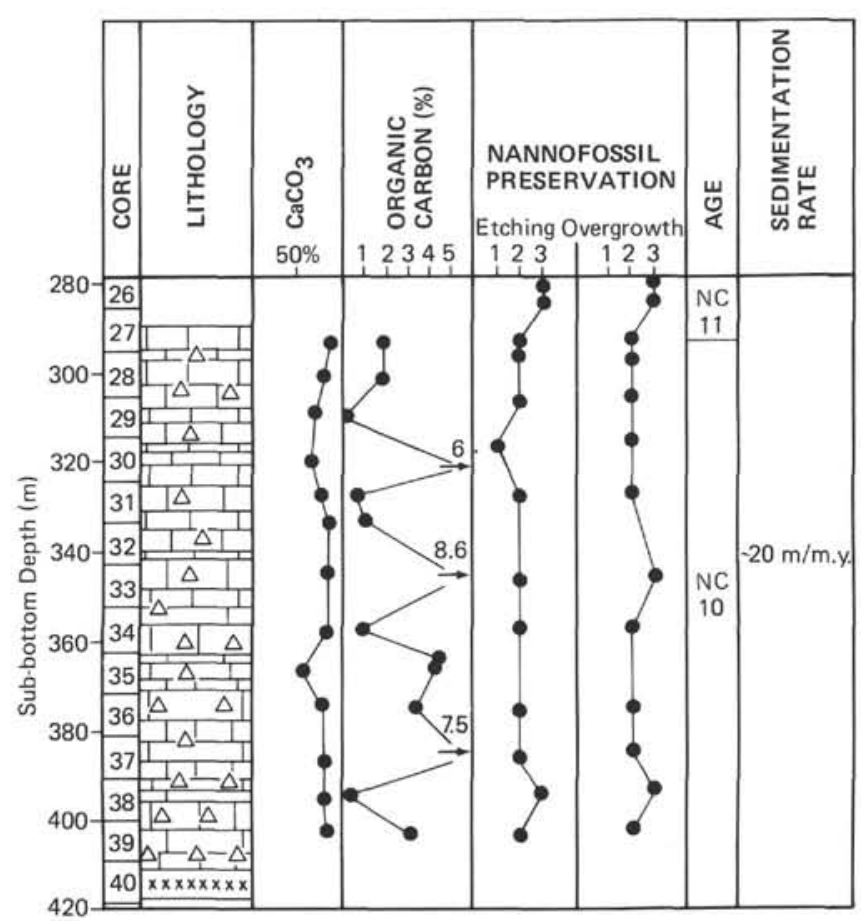

Figure 5. Mid-Cretaceous section at Site 465: lithology, geochemistry, nannolith preservation, and linear sediment-accumulation rate. 


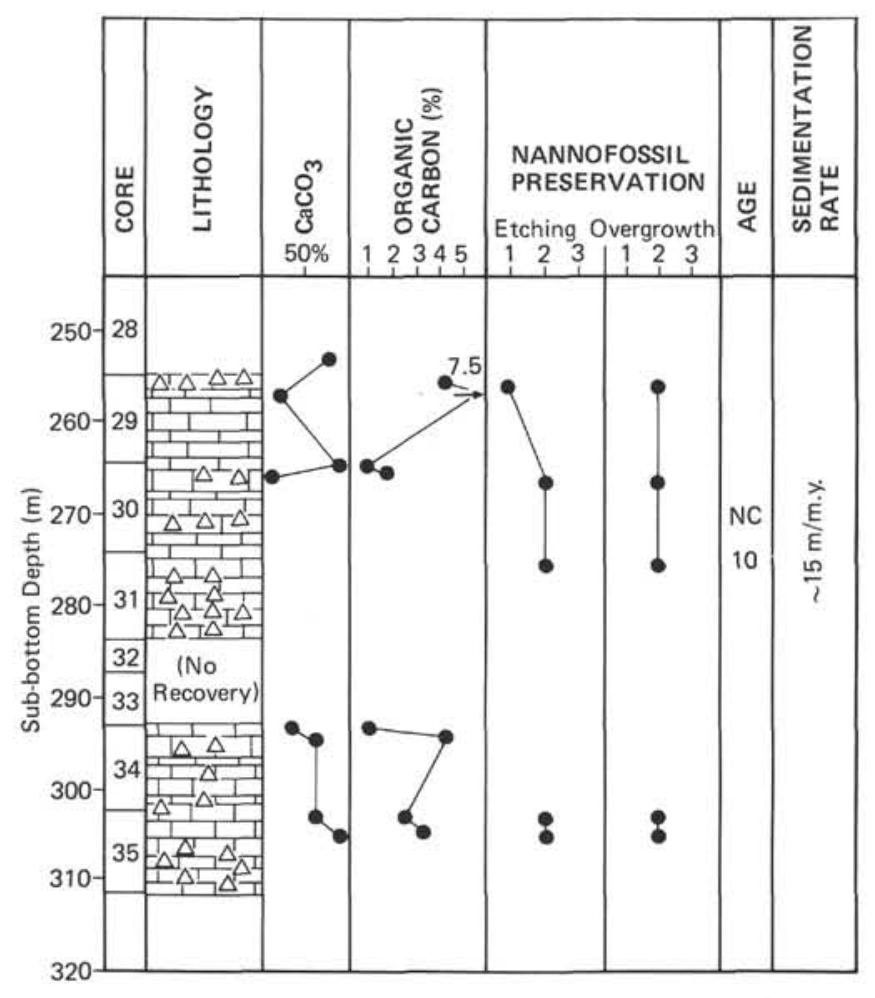

Figure 6. Mid-Cretaceous section at Site 466: lithology, geochemistry, nannolith preservation, and linear sediment-accumulation rate.

$62(1.3 \%)$ and $56(3.5 \%)$. The uppermost part of the mid-Cretaceous section (Cores 65 to 38) is composed of massive foraminifer chalks that extend to the lower Maastrichtian. They are off-white with light pink and green shades and contain abundant chert, which resulted in low core recovery. Carbonate contents are high, and organic-carbon values are very low. Thus, there is a slight indication of a "sapropel event" at Site 463 in the upper Magellanian (NC8), but no indication of a Tenerifian (NC11) anoxic event at this site.

The middle Cretaceous sedimentary sections recovered from Hess Rise cover a stratigraphic interval restricted to the upper part of the middle Cretaceous (Atlantian and Tenerifian). At Site 464, the recovery of middle Cretaceous rocks was very poor. Only three of the 23 cores recovered more than 1 meter of sediments. The predominant rock type is gray and reddish to darkbrown chert. Some of the chert vugs are filled with red and tan chalk that contains coccoliths of moderate to poor preservation. Dark-red and brown limestones, marlstones, and claystones occur in Cores 21, 29, 30 and 32. The hole bottomed in basalt. Calcium-carbonate contents are relatively low ( $\max .40 \%$ ), but few measurements have been made. Organic-carbon contents are low $(0-0.1 \%)$, except for one value of $4.3 \%$ in Core 32 . Conditions of sedimentation were largely oxidizing at this deep site.

The middle Cretaceous section at Site 465 (Hole $465 \mathrm{~A}$ ) consists of laminated olive-gray limestones with black chert and some ash-rich beds at the base which represent distal turbidites. Carbonate contents are generally high (70-90\%). In most intervals where organiccarbon values are high, carbonate values are low (11$33 \%$ ). Organic-carbon contents fluctuate, but many values between 2 and $3 \%$ were measured; peak values reach 6.1 to $8.6 \%$. The organic carbon appears to have a largely marine source (Dean et al., 1979) in this part of the Tenerifian (NC11/NC12) sapropel cycle.

At Site 466, mid-Cretaceous beds consist of olivegray, faintly laminated nannoplankton chalk and limestone with black chert, very similar to the sediments recovered nearby at Site 465 . They are also interpreted as distal turbidites.

The sedimentology and organic chemistry of the pelagic sediments in Cores 69 and 70 at Site 463 indicate an increased influx and preservation of terrestrial, rapidly buried organic debris. Other sediments rich in organic carbon in the Albian at Site 463, and the organic-rich sedments from Sites 465 and 466 , seem to be related to increased productivity, causing reduced oxygen content in the waters (see also Dean et al., 1979). As discussed later, coccolith assemblages seem to corroborate this hypothesis.

\section{PRESERVATION OF CALCAREOUS NANNOPLANKTON}

Nannoliths exhibit moderate to severe dissolution ("etching") in samples from sites at water depths close to or below the CCD (e.g., in the western Pacific). Secondary calcite overgrowths are more prevalent in shallow plateau sequences. Poor recovery in the chertrich sections compounds the problem, because the most strongly lithified parts of the section are preferentially recovered; coccoliths from these lithologies are often recrystallized beyond recognition. The middle Cretaceous nannoplankton assemblages recovered during Leg 62 , although not pristine, are among the best-preserved from the Pacific Ocean. The state of preservation of middle Cretaceous coccolith assemblages is expressed in the semi-quantitative visual preservation scale of Roth and Thierstein (1972), as modified by Roth (1973) for the Mesozoic.

The following degrees of etching are distinguished: E1: slightly jagged margins among delicate forms, delicate central structure damaged in some but not all specimens; E2: more-jagged outlines, delicate central structures frequently affected, more-delicate forms slightly fragmented; E3: only the more-robust forms are preserved, assemblages are enriched in Watznaueria and Cretarhabdus.

The following degrees of overgrowth are distinguished: O1: slight overgrowth on central structures and shield elements; O2: increased overgrowth, some of the more-delicate forms are sufficiently masked to make identification more difficult; $\mathrm{O} 3$ : only robust forms preserved; diversity reduced because of removal of delicate forms that serve as the source material for secondary calcite overgrowths and cements. 
Rarity is expressed in these terms: VB: virtually barren; only occasional coccoliths and fragments of coccoliths, often barely recognizable, mostly micrite grains; B: total absence of recognizable coccoliths.

Coccolith preservation at the various sites is listed in Table 1 and is graphically depicted in Figures 3 through 6 . None of the samples show pristine preservation. All of them show at least moderate overgrowths, with the exception of a strongly etched sample at Site 464. In general, the samples from Leg 62 cores are affected more by overgrowth than by etching. At Site 463 , the most-etched samples correlate with low calcium-carbonate content and unusually high organic-carbon content (Core 70, Section 5). Overgrowths are most pronounced in deeply buried multicolored and tuffaceous limestones (Cores 55-87).

At Site 463 , virtually barren samples, with only a few poorly preserved specimens of Watznaueria barnesae, and totally barren samples occur in parts of the tuffaceous and carbonaceous limestone sequence (Core 70) and in the clastic and detrital limestones (Cores 79-82, 89 to $91, C C)$. Dilution of the coccolith remains with detrital and volcanogenic matter resulted in low total concentration of coccoliths in the sediments. Decay of organic matter and diagenesis was responsible for the alteration and occasional total destruction of nannoliths in these intervals. At Site 464 (Cores 79-82, 89-91,CC) recovery was virtually restricted to strongly lithified rocks, such as cherts, with calcareous vug fillings, and also silicified limestones.

Thus, the material is mostly poorly preserved, and the assemblages have to be considered marginal at best for quantitative investigation. Preservation of nannoliths is considerably better at Sites 465 and 466 . In Hole $465 \mathrm{~A}$, preservation is poor in the limestones recovered in Core 26 and in Section 1 of Core 27, where carbonate contents are $90 \%$, and in the limestones from Cores 33 , 38 , and 40 . Moderate preservation was observed in the remaining cores and in all samples from Site 466.

Carbonate content in the middle Cretaceous intervals of Holes $465 \mathrm{~A}$ and 466 is generally high (55-99\%), with the exception of organic-carbon-rich intervals, where it drops to values as low as 6 to $30 \%$. Somewhat poorer preservation is associated with the most-organic-carbon-rich laminated limestone sections at these sites.

\section{COCCOLITH ASSEMBLAGES: LATITUDINAL, PRESERVATIONAL, AND TEMPORAL CHANGES}

The relative abundance of all species and some groups only identified to genus in the 32 samples studied are shown in Figures 7 through 10. Species concepts are summarized in the appendix. Closer inspections of these charts shows that of the more than 60 species (and genera) observed, only 10 to 12 occur more or less consistently in an abundance over $2 \%$ of the total assemblage. Because moderate to severe preservational changes have affected the nannolith assemblages, $2 \%$ was used as a lower limit for generalized nannofloral analysis. The more abundant forms and their maximum and minimum relative abundances at each site are as follows:

\begin{tabular}{lcccc}
\hline & $\begin{array}{r}\text { Site } \\
463\end{array}$ & $\begin{array}{r}\text { Site } \\
464\end{array}$ & $\begin{array}{c}\text { Site } \\
465\end{array}$ & $\begin{array}{c}\text { Site } \\
466\end{array}$ \\
\hline Watznaueria barnesae & $8-65 \%$ & $34-68 \%$ & $2-9 \%$ & $18-30 \%$ \\
Biscutum constans & $0-35 \%$ & $0-39 \%$ & $22-36 \%$ & $31-49 \%$ \\
Discorhabus ignotus & $1-9 \%$ & $0-2 \%$ & $1-8 \%$ & $1-3 \%$ \\
Zygodiscus erects & $1-20 \%$ & $0-5 \%$ & $23-28 \%$ & $9-30 \%$ \\
Z. elegans & $1-2 \%$ & $1 \%$ & $1-3 \%$ & $1-3 \%$ \\
Z. diplogrammus & $0-3 \%$ & $0-2 \%$ & $1-2 \%$ & $1-5 \%$ \\
Eiffellithus turriseiffeli & $3-16 \%$ & $0-4 \%$ & $6-16 \%$ & $2-4 \%$ \\
Parhabdolithus asper & $1-10 \%$ & $1 \%$ & $0-1 \%$ & $1 \%$ \\
P. splendens & $1-12 \%$ & $2-7 \%$ & $2-6 \%$ & $2-4 \%$ \\
Prediscosphaera cretacea & $1-8 \%$ & $0-3 \%$ & $1-3 \%$ & $1 \%$ \\
Cretarhabdus crenulatus & $2-11 \%$ & $1-2 \%$ & $1-2 \%$ & $1-2 \%$ \\
\hline
\end{tabular}

Species that occur in low to moderate abundance (but do not exhibit consistent patterns) and their total range in all sections include the following:

\begin{tabular}{ll}
\hline Lithraphidites carniolensis & $1-14 \%$ \\
Cruciellipsis chiastia & $0-4 \%$ \\
Cyclagelosphaera margareli & $0-12 \%$ \\
Vagalapilla matalosa & $0-5 \%$ \\
Watznaueria supracretacea & $0-9 \%$ \\
Parhabdolithus swinnertonii & $0-4 \%$ \\
Nannoconus spp. & $0-3 \%$ \\
Rucinolithus sp. & $0-7 \%$ \\
\hline
\end{tabular}

All other species do not exceed $5 \%$ in any sample and are generally in the 0 to $3 \%$ range, or occur only in scattered samples.

The list of abundant species and genera agrees well with observations from the Atlantic and Indian Oceans. A possible interpretation of distribution patterns for these predominant species has been determined for the Atlantic (Roth and Bowdler, in press). In order to facilitate the interpretation of middle Cretaceous nannoplankton distribution and the implication for paleoceanography, nannoplankton distribution in the Atlantic is outlined briefly, and species important for paleoceanographic interpretation are identified. A profile of species abundance in the best-preserved samples from sites along the eastern margin of the North Atlantic and continuing through the South Atlantic for the interval $\mathrm{NC10} / \mathrm{NC} 11$ is shown in Figure 11. An east-west profile of species abundances from Texas across the North Atlantic is shown on Figure 12.

The north-south profile starts with a sample from the Gault Clay that contains some high-latitude species (Serbiscutum primitivum and Zygodiscus sp. cf. Z. spiralis). The next station (Site 400) contains more Watznaueria barnesae, possibly because of some postdepositional dissolution during diagenesis of these organic-matter-rich shelf sediments. The samples from Sites 398 to 367 show little change in the overall abundance of the major species. Abundance of Watznaueria barnesae is low; Biscutum constans and Zygodiscus spp. abundances are high. In the largely isolated northern South Atlantic, Biscutum constans can totally dominate the nannolith assemblages. A peak of $59 \%$ Biscutum constans was observed at Site 364 in the sam- 


\begin{tabular}{|c|c|c|c|c|c|c|c|c|c|c|c|c|c|c|c|c|c|c|c|c|c|c|c|c|c|c|c|c|c|c|c|c|c|}
\hline Sample & Etching & Overgrowth & $\begin{array}{c}\text { NC } \\
\text { Zone }\end{array}$ & 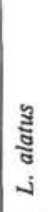 & 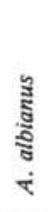 & 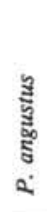 & 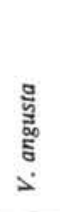 & $\begin{array}{l}\grave{y} \\
\text { ఫे } \\
\dot{2}\end{array}$ & 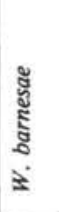 & 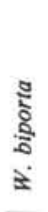 & 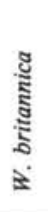 & 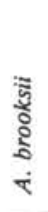 & $\begin{array}{l}\text { हूँ } \\
\text { हूँ } \\
\text { हूँ } \\
\text { ปn }\end{array}$ & 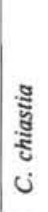 & 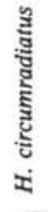 & 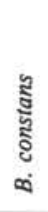 & 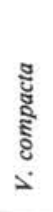 & 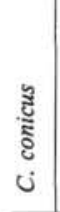 & 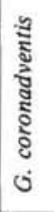 & 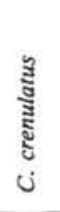 & 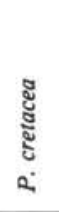 & 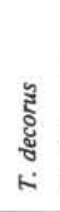 & 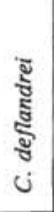 & 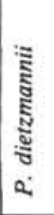 & 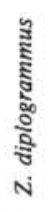 & 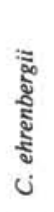 & 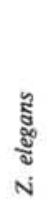 & 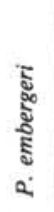 & 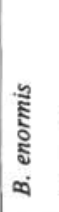 & $\begin{array}{l}\text { בัँ } \\
\text { ธूँ } \\
\text { N }\end{array}$ & 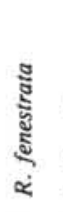 & 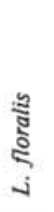 & $\begin{array}{l}\text { בี้ } \\
\text { ปี } \\
\text { N }\end{array}$ \\
\hline $463-38-1,12 \mathrm{~cm}$ & 1 & 2 & 11 & 1 & 1 & 1 & - & 2 & 21 & - & - & - & 1 & 1 & - & 8 & 1 & 1 & + & 4 & 8 & 1 & - & - & 2 & - & 1 & 1 & 1 & 20 & - & 2 & + \\
\hline $43-2,10$ & 2 & 2 & 11 & + & $i$ & + & - & 1 & 16 & - & - & - & 5 & 1 & - & 17 & $i$ & $i$ & + & 5 & 4 & + & - & - & 3 & 1 & 2 & + & - & 10 & - & - & + \\
\hline $43, \mathrm{CC}$ & 2 & 2 & 11 & 1 & 1 & 1 & - & 2 & 17 & - & - & 1 & 6 & - & - & 18 & + & + & 1 & 3 & 4 & 1 & - & - & 3 & 1 & 1 & + & - & 4 & - & - & 1 \\
\hline $44-1,78$ & 2 & 2 & 11 & - & 1 & 1 & - & 2 & 17 & - & - & 1 & 2 & 1 & - & 30 & + & + & + & 4 & 2 & + & - & - & 2 & 1 & 1 & 1 & + & 6 & - & 1 & + \\
\hline $46-1,57$ & 1 & 2 & 11 & - & + & 1 & - & 1 & 8 & - & - & + & 4 & - & - & 25 & 1 & - & + & 2 & 4 & + & - & - & 1 & 1 & 2 & 1 & - & 6 & + & 1 & 1 \\
\hline $48-1,75$ & 1 & 2 & 11 & + & 1 & 1 & - & 2 & 16 & + & + & 1 & 2 & 1 & - & 26 & 1 & 1 & + & 4 & 1 & + & - & + & 1 & + & 1 & - & + & 7 & - & 1 & - \\
\hline $48-1,140$ & 1 & 2 & 11 & + & 1 & 2 & + & 2 & 12 & + & - & - & 2 & + & - & 28 & - & + & + & 3 & 6 & 1 & - & - & 1 & 1 & 1 & 1 & - & 6 & - & 1 & + \\
\hline $48-3,20$ & 2 & 2 & 11 & + & i & 1 & - & 1 & 16 & - & - & - & 2 & + & - & 35 & 1 & + & + & 2 & 3 & - & - & - & 2 & 3 & 1 & + & - & 2 & - & 1 & - \\
\hline $48-3,95$ & 2 & 2 & 11 & - & - & 1 & - & 1 & 20 & - & + & + & 2 & + & - & 21 & 1 & - & + & 4 & 6 & + & - & + & 1 & 1 & 1 & + & + & 3 & - & 1 & - \\
\hline $52, \mathrm{CC}$ & 2 & 2 & 10 & - & - & + & - & 4 & 31 & - & - & - & 4 & 1 & - & 16 & 1 & 1 & - & 8 & 1 & - & - & - & 2 & - & 1 & - & - & 5 & - & 1 & 1 \\
\hline $54, \mathrm{CC}$ & 2 & 2 & 8 & - & - & 1 & + & 4 & 32 & - & + & - & 7 & $i$ & - & 6 & + & - & - & 9 & 3 & - & - & - & 2 & - & 2 & - & - & 3 & - & - & - \\
\hline $56-1,97$ & 2 & 3 & 7 & - & - & + & - & 3 & 45 & - & 1 & - & 2 & + & + & 1 & - & - & + & 11 & - & + & + & - & + & - & 2 & 1 & - & 1 & + & 1 & - \\
\hline $69-1,1$ & 2 & 2 & 6 & - & - & - & - & 10 & 24 & - & 1 & - & 14 & 4 & + & - & - & - & - & 2 & - & + & - & + & + & - & 1 & - & - & 1 & + & 3 & - \\
\hline $70-5,7$ & 3 & 2 & 6 & - & - & - & - & 9 & 65 & 1 & - & - & 1 & 1 & - & 1 & - & - & - & 7 & - & - & - & - & 1 & - & - & 1 & - & 2 & - & - & - \\
\hline $70-5,83$ & 3 & 2 & 6 & - & - & - & - & 10 & 56 & - & 1 & - & 2 & 3 & 1 & - & - & 1 & - & 2 & - & - & - & - & 1 & - & 1 & 1 & - & 1 & - & - & - \\
\hline $72-1,144$ & 3 & 2 & 6 & - & - & - & - & 6 & 61 & - & - & - & 7 & 2 & - & + & - & 2 & - & 2 & - & - & - & - & - & - & 1 & 1 & - & 2 & - & - & - \\
\hline
\end{tabular}

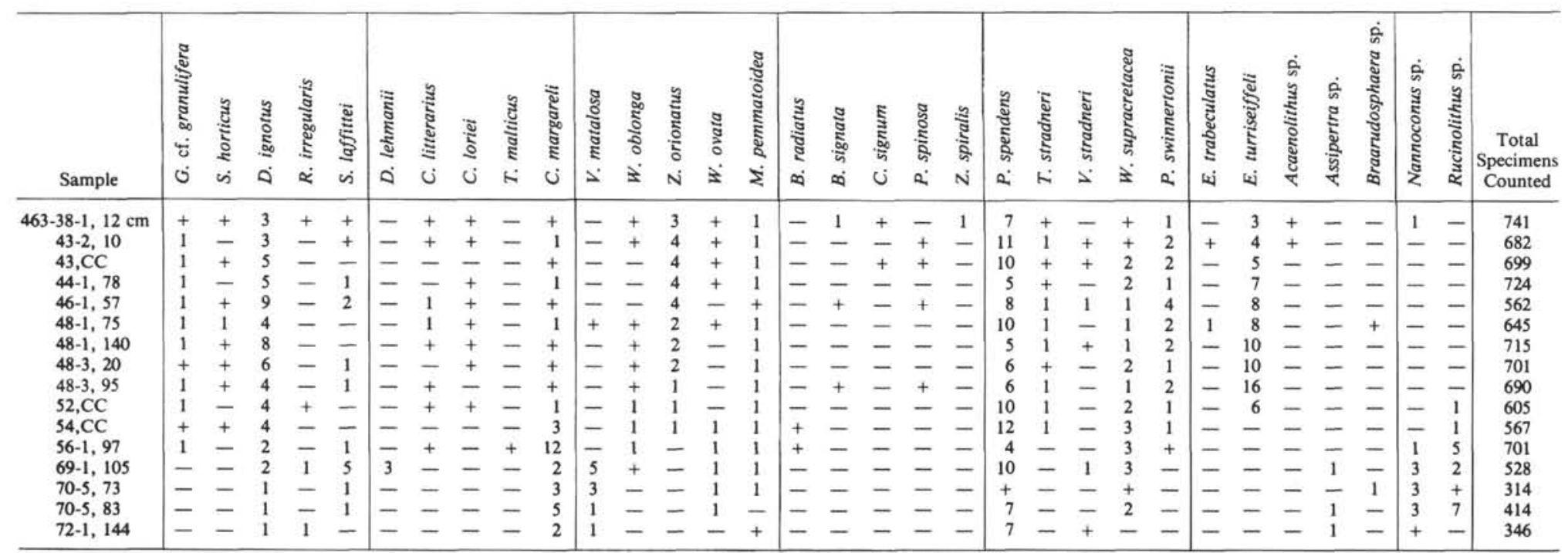

Figure 7. Relative abundance of nannoliths at Site 463 in percent of the total assemblage. The plus sign stands for abundances of less than $1 \%$, the minus sign for species that were not observed in the particular sample during counting. 

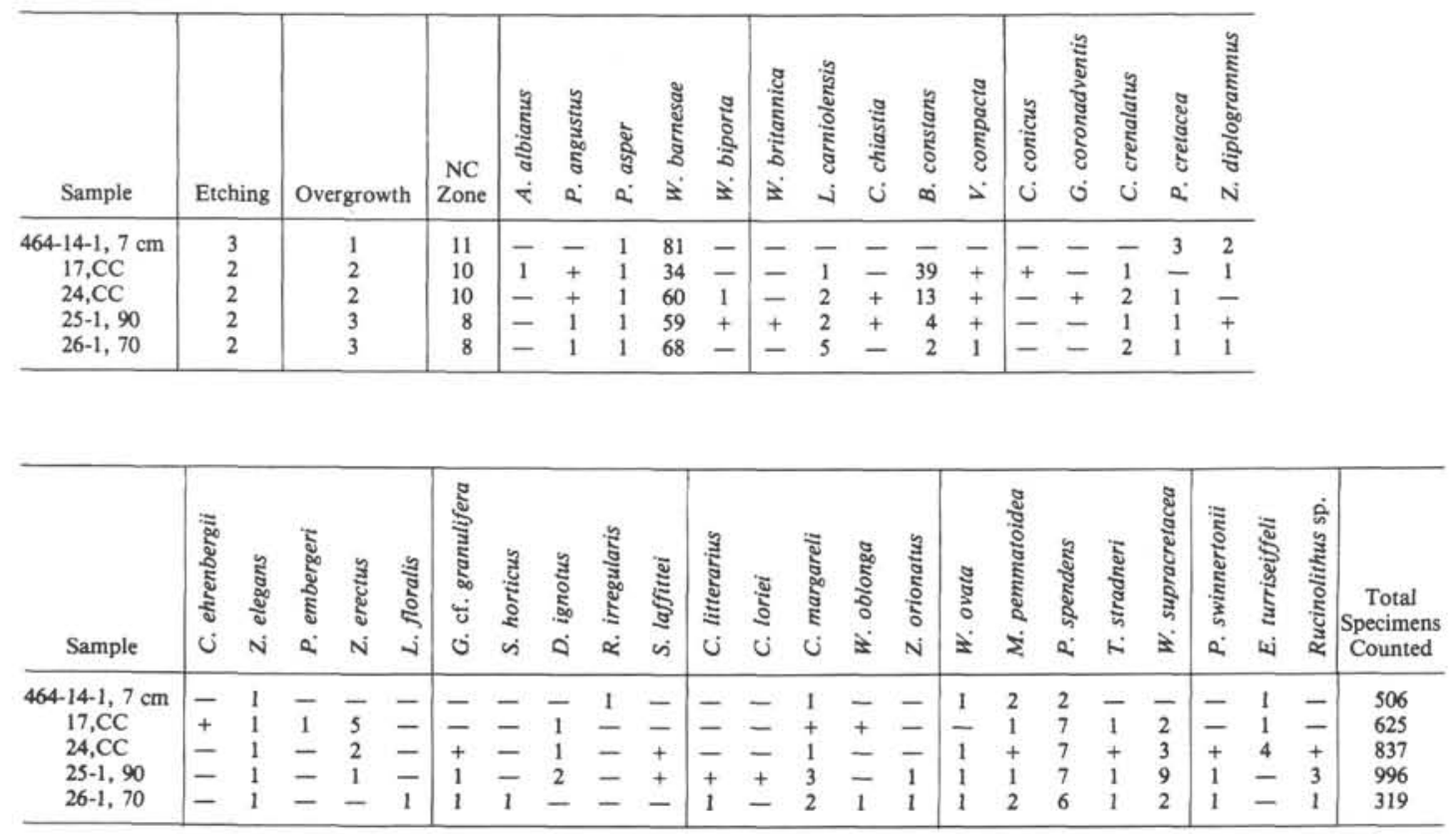

Figure 8. Relative abundance in percent of the total assemblage in the mid-Cretaceous of Site 464. Plus and minus signs mean the same as in Figure 7.

\begin{tabular}{|c|c|c|c|c|c|c|c|c|c|c|c|c|c|c|c|c|c|c|c|c|c|c|c|c|c|c|c|c|}
\hline Sample & Etching & Overgrowth & $\begin{array}{l}\text { NC } \\
\text { Zone }\end{array}$ & 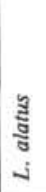 & 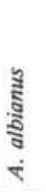 & 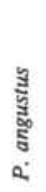 & 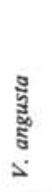 & 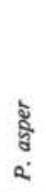 & 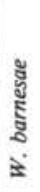 & 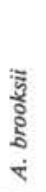 & 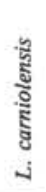 & $\begin{array}{l}\text { ปั้ } \\
\text { ธิँ } \\
ن\end{array}$ & $\begin{array}{l}\text { हूँ } \\
\text { जू } \\
\text { है } \\
\infty\end{array}$ & 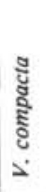 & 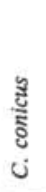 & 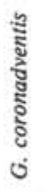 & 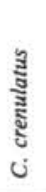 & 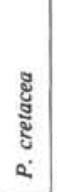 & 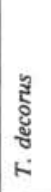 & 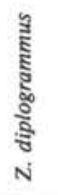 & 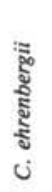 & $\begin{array}{l}\text { है } \\
\text { ปँ } \\
\text { N }\end{array}$ & 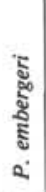 & $\begin{array}{l}\text { है } \\
\text { हू } \\
\text { हू } \\
\infty\end{array}$ & 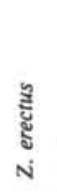 & 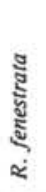 & $\underset{j}{\stackrel{y}{g}}$ & 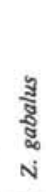 \\
\hline $465 \mathrm{~A}-27, \mathrm{CC}$ & 2 & 2 & 11 & 1 & - & 2 & - & 1 & 9 & - & 3 & - & 26 & 1 & - & - & 2 & 2 & + & 1 & - & 2 & + & - & 25 & + & - & - \\
\hline $28-1,38 \mathrm{~cm}$ & 2 & 2 & 11 & + & - & 1 & - & 1 & 8 & $\overline{-}$ & 2 & - & 26 & 1 & - & + & $i$ & i & 1 & i & + & 2 & + & + & 33 & - & - & - \\
\hline $29-1,133$ & i & 2 & 10 & - & + & + & - & - & 6 & - & 3 & + & 35 & - & 1 & - & 1 & i & $i$ & i & - & 3 & 1 & - & 26 & - & 1 & - \\
\hline $30-1,24$ & 1 & 2 & 10 & - & + & + & - & + & 8 & - & 3 & - & 36 & 1 & + & - & $i$ & $i$ & - & $i$ & - & 1 & - & + & 30 & - & 1 & - \\
\hline $36-1,63$ & 2 & 2 & 10 & - & - & 2 & - & 2 & 9 & + & 3 & - & 22 & $i$ & + & - & i & 2 & - & 2 & - & $i$ & - & - & 25 & - & 1 & - \\
\hline $37-1,60$ & 2 & 2 & 10 & - & - & 1 & + & + & 2 & - & 4 & - & 24 & 2 & - & + & 1 & 1 & + & 1 & - & + & - & + & 38 & - & - & 1 \\
\hline $39-1,68$ & 2 & 2 & 10 & - & - & 1 & - & 2 & 7 & - & 3 & 1 & 27 & 1 & - & 1 & i & i & - & 2 & - & 1 & - & - & 23 & - & 1 & - \\
\hline
\end{tabular}

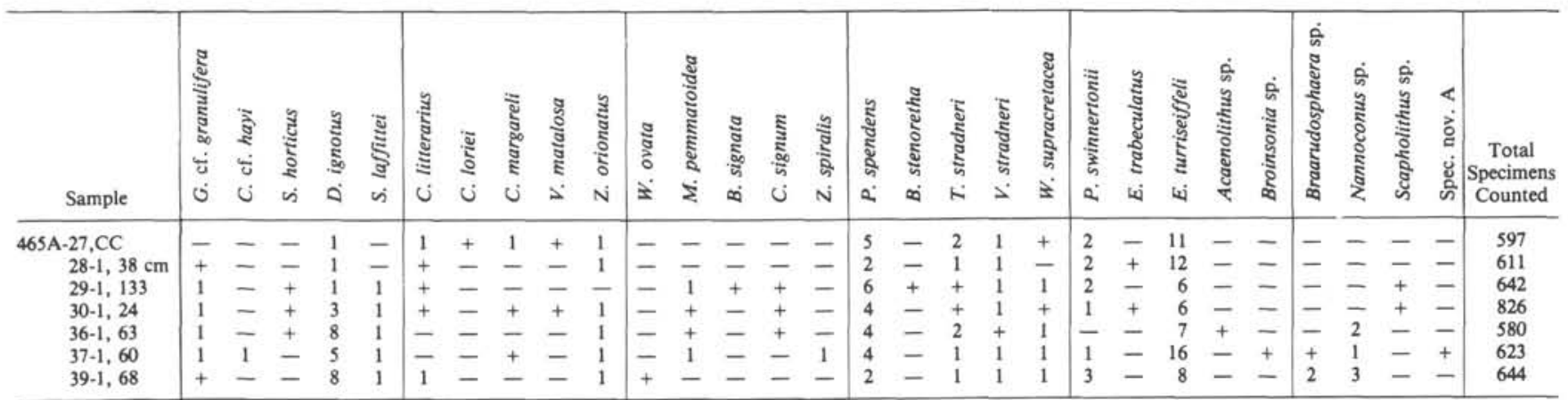

Figure 9. Relative abundance of nannoliths in percent of the total assemblage in the mid-Cretaceous of Site 465 . Plus and minus signs mean the same as in Figure 7.

ple used for the profile; other samples show lower values, similar to the ones found at Site 363. Assemblages of the Falkland Plateau are dominated by highlatitude forms (Seribiscutum primitivum, Zygodiscus spiralis, and Tranolithus orionatus). However, changes in nannoplankton assemblages in a wide tropical zone between $40^{\circ} \mathrm{N}$ and about $40^{\circ} \mathrm{S}$ seem relatively minor compared to changes we observe in an east-west profile across the North Atlantic (Fig. 12). The east-west profile, on the other hand, shows pronounced nannofloral trends. Epicontinental assemblages from Texas contain relatively abundant Biscutum constans and Eifellithus turriseiffeli, but relatively low abundances of Zygodiscus spp. At the Blake Nose (Site 390), Biscutum con- 

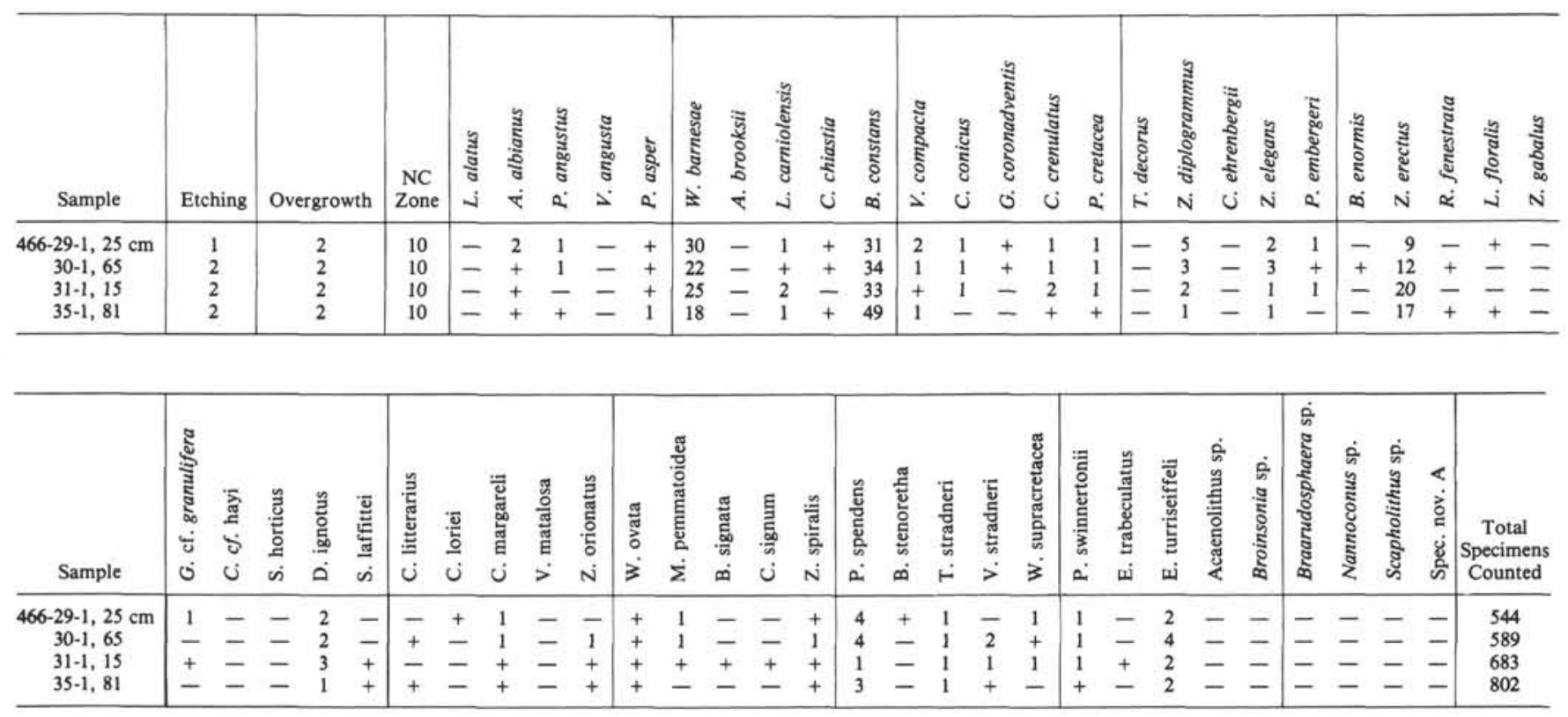

Figure 10. Relative abundance of nannoliths in percent of the total assemblages in the mid-Cretaceous at Site 466 . Plus and minus signs mean the same as in Figure 7.

stans is fairly abundant, but Zygodiscus erectus, $Z$. elegans, and $Z$. diplogrammus are much less common. Many rare forms occur at Site 390 , so that only $65 \%$ of the assemblage is expressed by the species shown on the profile. Watnaueria barnesea is more abundant at Site 390 and remains high at Sites 391, 418, 386, and 137. Parhabdolithus splendens and $P$. asper are more abundant in eastern basin and central North Atlantic sites than along the eastern and western continental margins. These relatively solution-resistant species show muchreduced abundances in the western North Atlantic. Relative abundances of the major nannolith species in the best-preserved assemblages from the shallowest sites on the eastern and western margins of the North Atlantic differ considerably - by as much as a factor of ten (Fig. 12). This seems to indicate that one cannot account for the nannofloral distribution patterns simply by invoking differences in preservation.

Indicators of more-neritic conditions, such as Nannoconus and Braarudosphaera, are observed in Texas and on the Blake Nose and at Site 391, where they are possibly redeposited in part from shallower water at the latter site.

This brief discussion of nannofloral trends in the upper part of the middle Cretaceous of the Atlantic allows us to identify the following species that are indicative of particular paleoceanographic conditions:

1) High-latitude forms: Seribiscutum primitivum Zygodiscus cf. spiralis Tranolithus orionatus

2) High-productivity/high-surface-water-fertility (“'upwelling”) forms:

\section{Biscutum constans}

Zygodiscus erectus

(or total Zygodiscus spp.)
3) Indicators of neritic conditions: (continental margin, shallow plateaus)

Nannoconus spp.

Braarudosphaera

Broinsonia spp.

4) Dissolution residual assemblages (excluded from our Atlantic profiles):

\section{Watznaueria barnesae}

5) Restricted sea assemblage (South Atlantic): highly variable assemblages with almost monospecific assemblages of Biscutum constans, Zygodiscus spp., Corrolithion spp.

With this knowledge of how ecologic preference and preservational aspects affect nannoplankton assemblages, it is now possible to interpret the nannolith distribution in a north-south profile in the tropical Pacific (Leg 62 sites) for the interval late NC10 to early NC11 (Fig. 13) in order to detect possible latitudinal trends. The major difference between the assemblages at Sites 463 and 465 is a much greater abundance of Zygodiscus erectus and a low abundance of Discorhabdus ignotus at the latter site. The relative abundance of Biscutum constans is almost the same at all the sites; this indicates its relatively great resistance to dissolution and diagenetic alteration. A decrease in the relative abundances of Watznaueria barnesae, Eiffellithus turriseiffeli, and Prediscosphaera cretacea seems of minor significance and is probably largely due to differences in preservation. The major differences in nannolith assemblages at Sites 463 and 465 are best explained by more-fertile surface water at the latter site; a very small difference in surface-water temperature might have had some influence also.

The comparison of coccolith assemblages at Sites 465 and 466 is most interesting because the two sites are only $50 \mathrm{~km}$ apart and the sedimentary facies are almost iden- 

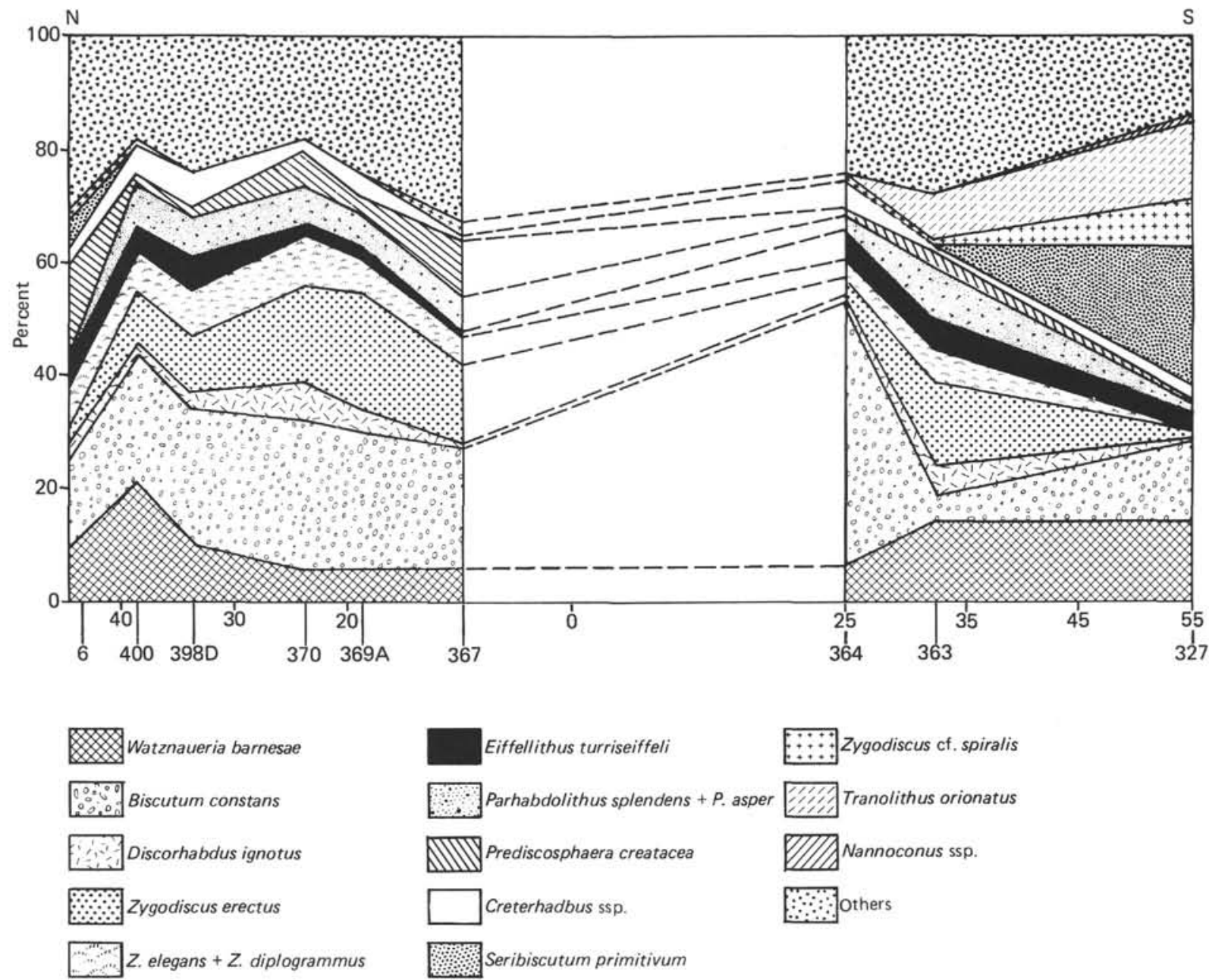

Figure 11. Plot of late mid-Cretaceous ( $\mathrm{NC10} / \mathrm{NC11})$ nannolith ratios versus latitude in a north-south transect from southeastern England along the eastern continental margin of the North Atlantic and through the South Atlantic to the Falkland Plateau. The following samples with the best preservation were used: 6 = Gault Clay; $400=$ DSDP 400A-62-1, $56 \mathrm{~cm}$; Bed XII, Copt Point, SE England; $398=$ DSDP 398D-57-3, $50 \mathrm{~cm} ; 370=$ DSDP $370-24-2,60 \mathrm{~cm} ; 369 \mathrm{~A}=$ DSDP $369 \mathrm{~A}-41-2,96 \mathrm{~cm} ; 367=$ DSDP $367-20-2,100 \mathrm{~cm} ; 364=$ DSDP $364-28-1,55 \mathrm{~cm} ; 363=$ DSDP $363-28-2,98 \mathrm{~cm} ; 327=$ DSDP $327-15-2,87 \mathrm{~cm}$.

tical (but show a difference in water depth of half a kilometer). The changes in relative abundance of the major nannolith species at these two sites was likely caused by differences in preservation; it seems highly improbable that a major water-mass boundary passed between the two sites and caused the differences in observed species composition. The most drastic change is an increase in the abundance of Watznaueria barnesae (a solutionresistant form) at Site 466. The ratios of Biscutum constans, Eiffellithus turriseiffelli, Zygodiscus elegans + $Z$. diplogrammus, and Parhabdolithus splendens $+P$. asper remain almost unchanged. However, Zygodiscus erectus decreases drastically in relative abundance. The best-preserved sample at Site 464 has a composition very similar to Site 466 , with somewhat more-abundant Biscutum constans and less-abundant Zygodiscus erectus at Site 464. Again, these small differences in nannofloral composition are largely attributed to differences in preservation, the assemblages at Site 464 being much more poorly preserved than the ones at Site 466 , because of greater water depth of the former and hence greater preservational changes. A comparison of the well-preserved assemblages at Sites 465 and 466 with assemblages in the Atlantic shows that Biscutum constans is a little more abundant in the tropical Pacific than it is in the Atlantic along the eastern margin (off Africa) or in epicontinental samples from Texas. Zygodiscus erectus is as abundant at Site $\mathbf{4 6 5}$ as in samples from the eastern basin of the Atlantic. This is indicative of high-productivity, possibly along an equatorial divergence. Common radiolarians in these sediments and high sedimentation rates support this hypothesis.

In order to find how nannolith assemblages changed through time, ratios of the dominant species were plotted against age for each site (Fig. 14). The temporal species plot at Site $\mathbf{4 6 3}$ shows interesting trends. Lower middle Cretaceous assemblages (NC6 and NC7) show unusually abundant Watznaueria barnesae and relatively abundant Parhabdolithus splendens and $P$. asper. Such assemblages are indicative either of low original 

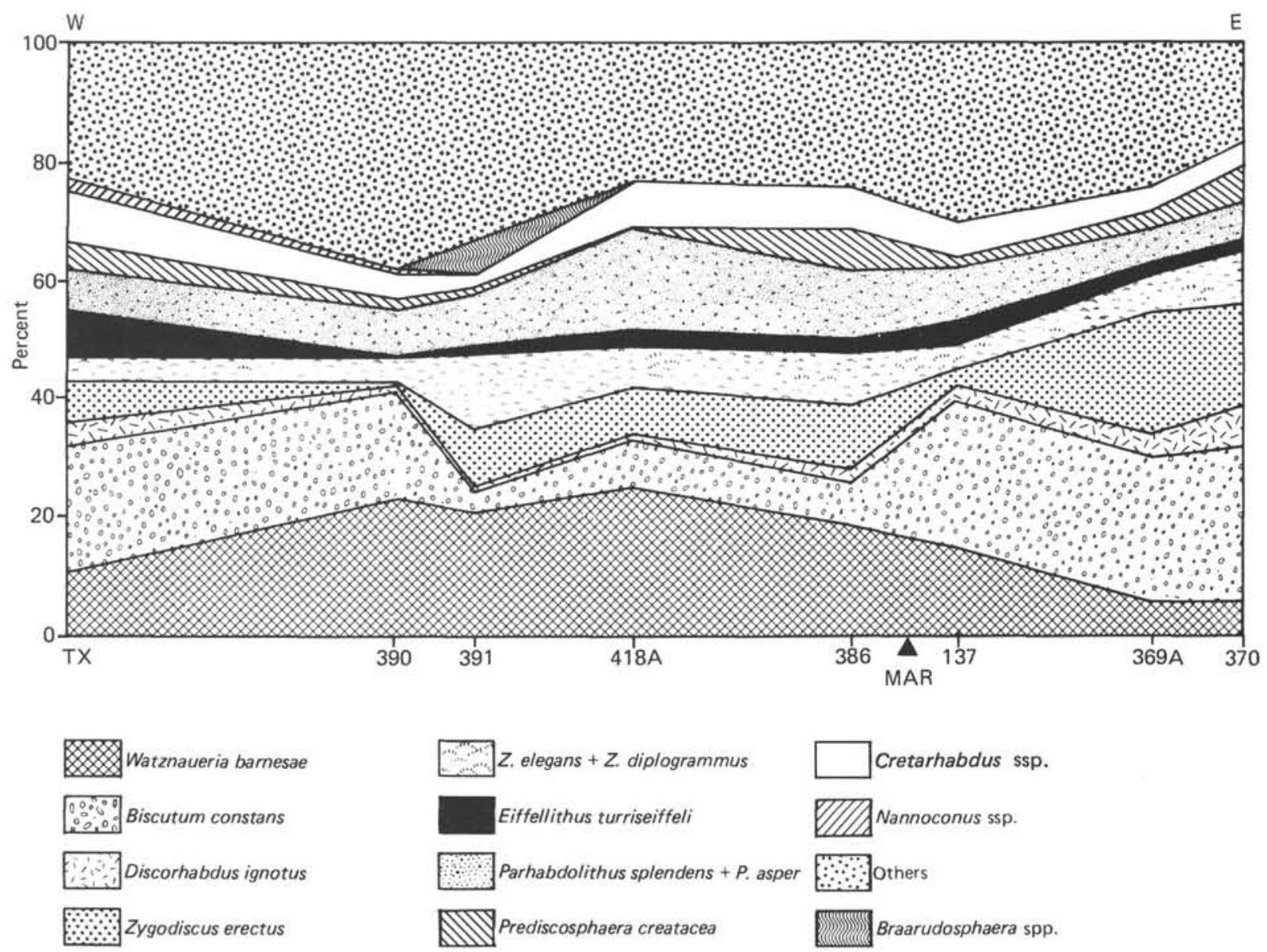

Figure 12. Plot of latest mid-Cretaceous ( $\mathrm{NC10} / \mathrm{NC11})$ nannolith ratios along a west-east profile from Texas to the Blake Nose and across the North Atlantic continental margin. The following best-preserved samples were used: TX = Grayson Mar, Grayson Bluff (Hill, 1976, $\Delta 6259$ ); 390 = DSDP 390-3-1, $143 \mathrm{~cm} ; 391 \mathrm{C}=$ DSDP 391C-9-1, $30 \mathrm{~cm} ; 418=$ DSDP 418A-10-1, $55 \mathrm{~cm} ; 386$ $=\operatorname{DSDP} 386-55-6,44 \mathrm{~cm} ; 137=$ DSDP $137-16-4,148 \mathrm{~cm} ; 369 \mathrm{~A}=$ DSDP $369 \mathrm{~A}-41-3,96 \mathrm{~cm} ; 370=$ DSDP $370-24-2,60 \mathrm{~cm}$. MAR = approximate position of the Mid-Atlantic Ridge. Species symbols as in Figure 11.

diversity because of unfavorable surface-water conditions, or of the effect of preservational changes. The beds rich in detrital organic carbon from terrestrial sources are particularly rich in Watznaueria barnesae. Perhaps the highly turbid surface water near the islands that furnished the detrital matter was an unfavorable habitat for other species. Also, carbon dioxide production by disintegrating organic matter in the sediment might be partly responsible for secondary differential dissolution of coccolith species. Samples just above this interval contain very abundant Lithraphidites carniolenis, a species whose ecological preference is not clearly understood at the present time. In zone NC8 (middle Albian) Watznaueria barnesae reaches a second peak in abundance and then steadily declines until the top of the middle Cretaceous. This decrease of Watznaueria barnesae is accompanied by a steady increase in Biscutum constans. Parhabdolithus splendens and $P$. asper increase in the lower and middle Albian and decrease in the upper Albian. Eiffellithus turriseiffeli increases rapidly after its first appearance and fluctuates in abun- dance near the top of the section. Zygodiscus spp. do not increase very much in that interval (NC10); therefore we cannot attribute the temporal changes in nannolith assemblages solely to changes in preservation. Closer sample spacing in the uppermost middle Cretaceous zone NC11 (Tenerifian or lower Cenomanian) results in greater fluctuations in abundance of important nannoliths. Biscutum constans and Zygodiscus spp. seem to display the greatest variability. Whether such changes are cyclic and are caused by changes in surfacewater conditions or preservation could be tested by taking more closely spaced samples. The overall nannofloral assemblage change at Site 463 between 100 m.y. and 95 m.y. reflects a trend from more-neritic conditions (also indicated by the presence of Nannoconus in zones NC6 and NC7) to more-oceanic and better-preserved assemblages deposited under oxygenated deep water during the late part of the middle Cretaceous. The presence of Nannoconus during the middle Cretaceous at the Mid-Pacific Mountains and Hess Rise shows clearly that this species did occur in shallow regions of 

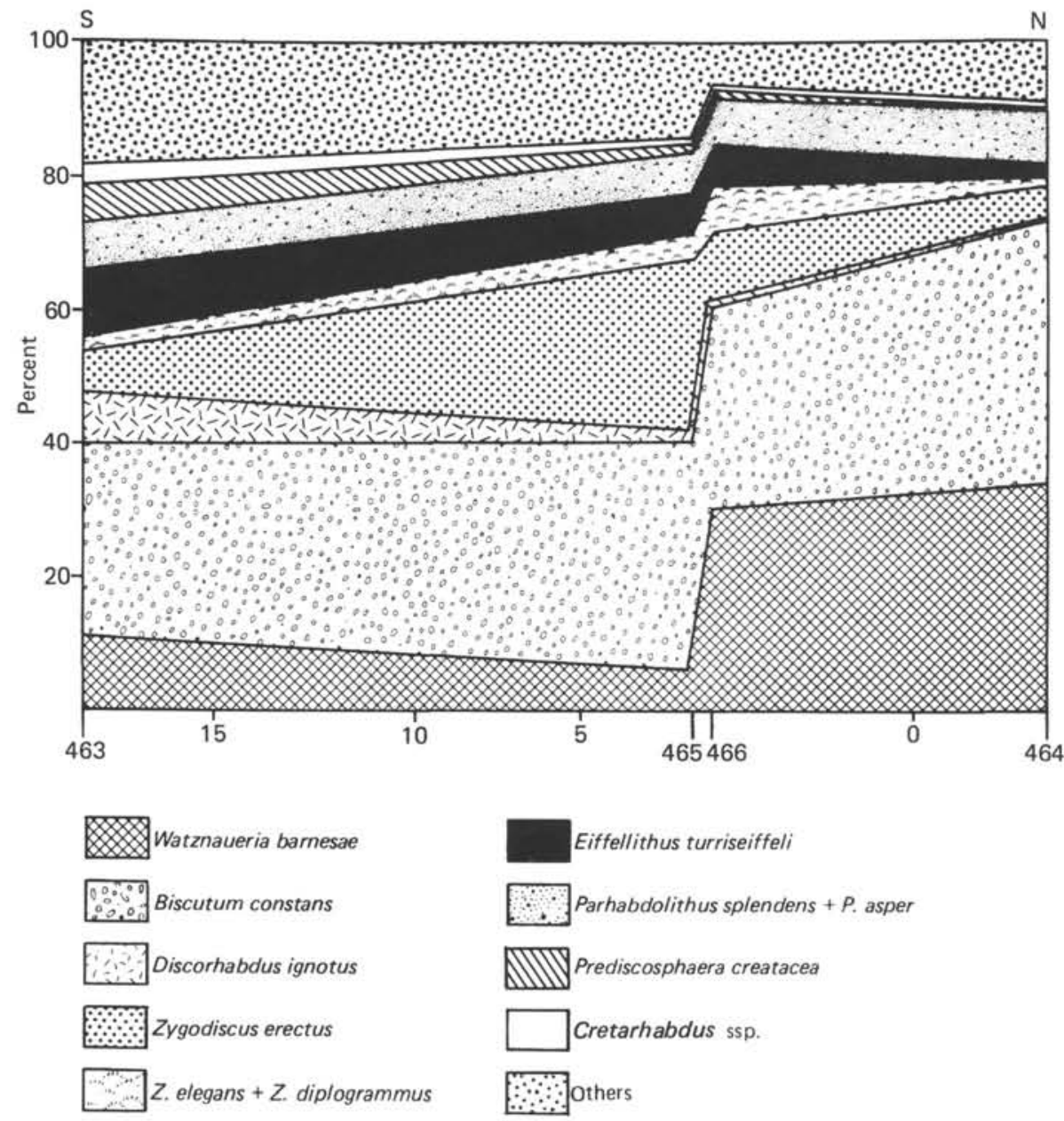

Figure 13. Nannolith species ratios versus latitude in a south-north profile from the Mid-Pacific Mountains to northern Hess Rise for the latest mid-Cretaceous (NC10/NC11). Samples: $463-48-1,140 \mathrm{~cm} ; 465 \mathrm{~A}-29-1,133 \mathrm{~cm} ; 466-29-1,25 \mathrm{~cm} ; 464-17, \mathrm{CC}$. Note that the latitudinal scale is expanded by a factor of 2 north of $5^{\circ} \mathrm{S}$. Species symbols as in Figure 11.

the tropical oceans far from land. It was also found in the lowermost Cretaceous at the Magellan Rise (Site 167) by Roth (1973).

Site 463 did not reach the equatorial high-productivity zone during the middle Cretaceous (Table 2). Biscutum constans and Zygodiscus spp. are not as abundant at Sites 463 in zones NC10/NC11 as at equatorial Sites 465,466 , and 464 . Also, sedimentation rates are not as high at Site 463 as at Sites 465 and 466 , and the latest mid-Cretaceous "sapropel cycle" is missing at Site 463 . This is an indication that Site $463 \mathrm{had}$ not reached the equatorial region of high productivity by the late middle Cretaceous; it did not reach it until the Maastrichtian.

At Sites 465 and 466 , temporal changes in species abundance are relatively small. Biscutum constans and Zygodiscus spp. remain high throughout zones NC10 and NC11. High content of organic-carbon largely of marine origin (Dean et al., 1979) seems a further indication of fairly high production in the surface water, associated with high nutrient content possibly caused by an equatorial divergence.
Temporal changes at Site 464 are largely due to changes in preservation that seem to mask all primary changes in nannoplankton biocoenoses.

Although equatorial middle Cretaceous sections have not yet been sampled in other ocean basins, it is possible to interpret the large-scale nannofloral patterns in the equatorial Pacific middle Cretaceous. A zone of high productivity did exist, and we can assume that, although surface circulation was more sluggish because of smaller temperature gradients, a system of gyres and an equatorial convergence existed during the middle Cretaceous, at least in the Pacific Ocean.

\section{SUMMARY AND CONCLUSIONS}

Calcareous-nannoplankton assemblages from the equatorial Pacific, although affected by preservational changes, have retained the major original spatial and temporal nannofloral trends. Dissolution and overgrowth result in an increase in the abundance of Watznaueria barnesae and a decrease in the abundance of one of the high-fertility indicators, Zygodiscus erectus, but they hardly affect the abundance of Biscutum con- 

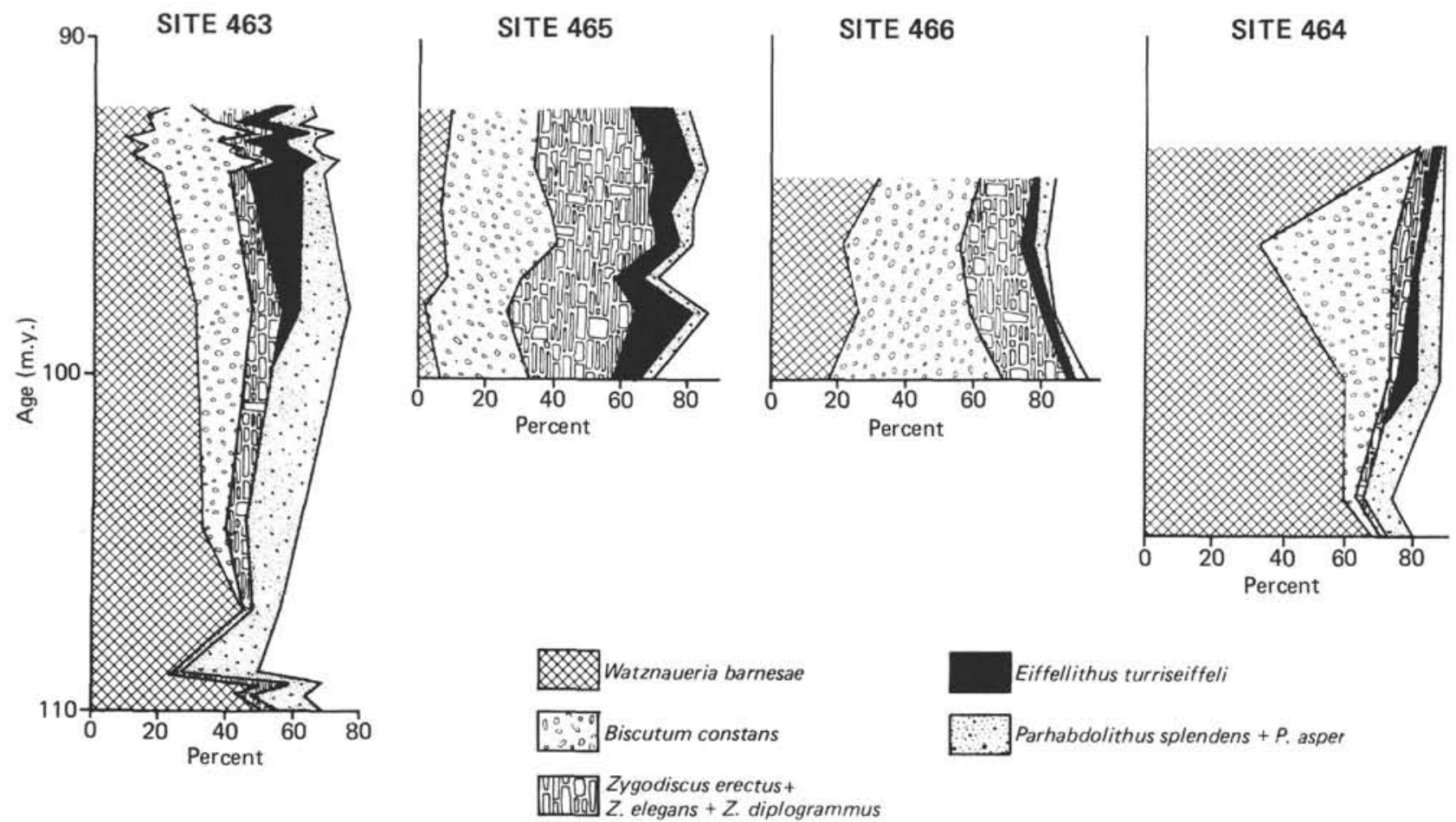

Zygodiscus erectus+
Z. elegans $+Z$. diplogrammus

Figure 14. Temporal fluctuations of important nannolith species in mid-Cretaceous sections at Leg 62 sites. Species symbols as in Figure 11, except for one new composite symbol, which represents Discorhabdus ignotus + Zygodiscus erectus $+Z$. elegans.

stans, the other indicator species of high surface-water fertility. Equatorial Pacific middle Cretaceous assemblages contain both of these indicator species of high surface-water fertility in great abundance during the interval NC10/NC11 (Argusian and Tenerifian or late Albian-Cenomanian). This indicates surface-water currents in the form of two gyres and an equatorial divergence that resulted in high surface-water productivity. The increased production of organic matter in an ocean with warm, intermediate and deep waters that contained little original dissolved oxygen was probably sufficient to cause mid-water anoxia in the tropical Pacific during the middle Cretaceous. Injection of oxygen-depleted deep water from the Atlantic into the Pacific at a depth of 1 to $2 \mathrm{~km}$ seems unnecessary and also unlikely, because of the lack of cold, dense bottom waters in the $\mathrm{Pa}$ cific which could have been denser than the more-saline waters injected from the Atlantic (Table 3). Middle Cretaceous organic-carbon-rich sediments are very localized in their occurrence in the Pacific and are generally associated with high sedimentation rates in the equatorial zone or in proximity to island chains. There is a need for detailed investigations of assemblages from additional drill sites, and also for a combination of micropaleontological, sedimentological, and geochemical studies of such sections in order to obtain a more complete picture of the middle Cretaceous paleoceanography of the Pacific.

\section{ACKNOWLEDGMENTS}

This research was supported by National Science Foundation Grant OCE 76-21561, and the samples used were recovered through
Table 3. Estimates of possible $\sigma_{t}$ values for surface and deep waters in the middle Cretaceous.

\begin{tabular}{cllll}
\hline & \multicolumn{4}{l}{ Density $\left(\sigma_{t}\right)$ for the following salinities } \\
\cline { 2 - 5 } Temperature & \multicolumn{1}{c}{$30 \%$} & $33 \%$ & \multicolumn{1}{c}{$36 \%$} & $39.99 \%$ \\
\hline $29^{\circ}$ & 18.34 & 20.59 & 22.85 & 25.84 \\
$20^{\circ}$ & 20.98 & 23.26 & 25.54 & $28.58(4)$ \\
$15^{\circ}$ & 22.15 & $24.45(2)$ & $26.65(3)$ & 29.27 \\
$12^{\circ}$ & 22.73 & 25.05 & 26.65 & 30.47 \\
\hline
\end{tabular}

Note: Estimates for surface-water temperatures are 15$29^{\circ} \mathrm{C}$, and for bottom waters $12-15^{\circ} \mathrm{C}$. For salinities, maximum values in restricted marginal seas are used as an analogue.

(1) = Possible minimum densities for high latitude surface waters in areas of high precipitation.

(2) $=$ Surface water densities in areas of reduce precipitation and possible bottom water densities in ocean basins without influx of high salinity waters.

(3) $=$ Possible densities for high salinity intermediate and bottom water in the Atlantic.

(4) = Maximum densities for high-salinity waters forming in restricted seas.

the assistance of the National Science Foundation. I thank Keith Krumbach (University of Utah) for help with sample preparation and photomicrographs and for editorial assistance. Discussions with Hans Thierstein and Wolf Berger (Scripps Institution of Oceanography) have been helpful in many ways. I am grateful to Jörn Thiede (University of Oslo), Tracy Vallier (U.S. Geological Survey, Menlo Park), and Pavel Cepek (Bundesanstalt für Geowissenschaften and Rohstoffe, G.F.R.) for letting me study these mid-Cretaceous sections, and to the other shipboard scientists for providing valuable background information. Once again I would like to express my gratitude to all who have helped to make the Deep Sea Drilling Project such a splendid success. I thank Kevin Furlong and Dave Chapman for help 
with plate rotations. I thank H. R. Thierstein (Scripps Institution of Oceanography) and A. A. Ekdale (University of Utah) for critical reviews of this paper.

\section{REFERENCES}

Arthur, M. A., 1979. Paleoceanographic events-recognition, resolution, and reconsideration. Rev. Geophys. Space Phys., 7:14741494.

Berger, W.H., 1979. Impact of deep-sea drilling on paleoceanography. In Talwani, M., Hay, W., and Ryan, W. B. F. (Eds.), Deep Drilling Results in the Atlantic Ocean: Continental Margins and Paleoenvironments: Washington (Am. Geophys. Union), pp. 297-314.

Berger, W. H., and Roth, P. H., 1975. Oceanic micropaleontology: progress and prospect. Rev. Geophys. Space Phys., 13:561-585, 624-635.

Berger, W. H., and Winterer, E. L., 1974. Plate stratigraphy and the fluctuating carbonate line. In Hsü, K. J., and Jenkyns, H. (Eds.), Pelagic Sediments on Land and Under the Sea: Spec. Pub. Internat. Assoc. Sedimentol., 1:11-48.

Black, M., 1971. Coccoliths of the Specton Clay and Suterby Marl. Yorkshire Geol. Soc. Proc., 38:381-424.

1972. British Lower Cretaceous coccoliths, I, Gault Clay. Palaeontogr. Soc. Monogr., Pt. 1:1-48.

1973. British Lower Cretaceous coccoliths, I, Gault Clay. Palaeontogr. Soc. Monogr., Pt. 2:49-112.

1975. British Lower Cretaceous coccoliths, I, Gault Clay, Palaeontogr. Soc. Monogr., Pt. 3:113-142.

Dean, W. E., Thiede, J., and Claypool, G. E., 1979. Origin of organic-rich limestones of mid-Cretaceous age, mid-Pacific Mountains and southern Hess Rise, Central North Pacific Ocean. Abs. Prog., 1979 Annual Meet., Geol. Soc. Am., p. 411.

Habib, D., 1979. Sedimentary origin of north Atlantic Cretaceous palynofacies. In Talwani, M., Hay, W., and Ryan, W. B. F. (Eds.), Deep Drilling Results in the Atlantic Ocean: Continental Margins and Paleoenvironments: Washington (Am. Geophys. Union), pp. 420-437.

Haq, B. U., and Lohmann, G. P., 1976. Early Cenozoic calcareous nannoplankton biogeography of the Atlantic ocean. Mar. Micropaleont., 1:119-194.

Hays, J. D., and Pittman, W. C., 1973. Lithospheric plate motions, sea level changes and climatic and ecological consequences. $\mathrm{Na}$ ture, 246:18-22.

Hill, M. E., 1976. Lower Cretaceous calcareous nannofossils from Texas and Oklahoma. Palaeontographica, Abt. B, Lfg. 4-6: 103-179.

Honjo, S., 1977. Biogeography and provincialism of living coccolithophorids in the Pacific Ocean. In Ramsay, A. T. S. (Ed.), Oceanic Micropalaeontology (Vol. 2): London (Academic Press), pp. 951972.

Lancelot, Y., and Larson, R. L., 1975. Sedimentary and tectonic evolution of the north-western Pacific. In Larson, R. L., Moberly, R., et al., Init. Repts. DSDP, 32: Washington (U.S. Govt. Printing Office), 925-939.

Loeblich, A. R., Jr., and Tappan, H., 1966. Annotated index and bibliography of the calcareous nannoplankton. Phycologia, 5:81. 1968. Annotated index and bibliography of the calcareous nannoplankton, II: J. Paleont., 42:584.

1969. Annotated index and bibliography of the calcareous nannoplankton, III: J. Paleont., 43:568.

,1970a. Annotated index and bibliography of the calcareous nannoplankton, IV: J. Paleont., 44:558.

, 1970b. Annotated index and bibliography of the calcareous nannoplankton, V: Phycologia, 90:157.

, 1971. Annotated index and bibliography of the calcareous nannoplankton, VI: Phycologia, 10:315.

1973. Annotated index and bibliography of the calcareous nannoplankton, VII: J. Paleont., 47:715-759.

Manivit, H., Perch-Nielsen, K., Prins, B., et al., 1977. Mid-Cretaceous calcareous nannofossil biostratigraphy. Koninkl. Nederl. Akad. Wetenschappen (Amsterdam) Proc., ser. B, 80:169-181.

McIntyre, A., and McIntyre, R., 1971. Coccolith concentrations and differential solution in oceanic sediments. In Funnell, B. M., and
Riedel, W. R. (Eds.), The Micropalaeontology of Oceans: Cambridge (Cambridge Univ. Press), pp. 253-261.

Parsons, B., and Sclater, J. G., 1977. An analysis of the variation of ocean floor bathymetry and heat flow with age. J. Geophys. Res., $82: 803-827$.

Roth, P. H., 1973. Calcareous nannofossils-Leg 17, Deep Sea Drilling Project. In Winterer, E. L., Ewing, J. I., et al., Init. Repts. DSDP, 17: Washington (U.S. Govt. Printing Office), 695-795. , 1978. Cretaceous nannoplankton biostratigraphy and oceanography of the northwestern Atlantic Ocean. In Benson, W. E., Sheridan, R. E., et al., Init. Repts. DSDP, 44: Washington (U.S. Govt. Printing Office), 731-759.

Roth, P. H., and Berger, W. H., 1975. Distribution and dissolution of coccoliths in the South and Central Pacific. Cushman Foundation Foram. Res., Special Publ., 13:87-113.

Roth, P. H., and Bowdler, J. L., in press. Middle Cretaceous calcareous nannoplankton biogeography and oceanography of the Atlantic Ocean. In Douglas, R. G., Winterer, E. L., and Warme, J. (Eds.), A Decade of Deep Ocean Drilling, SEPM Memoir.

Roth, P. H., and Coulbourn, W. T., in press. Floral and solution patterns of coccoliths in surface sediments of the North Pacific. Mar. Micropaleont.

Roth, P. H., and Thierstein, H., 1972. Calcareous nannoplankton: Leg 14 of the Deep Sea Drilling Project. In Hayes, D. E., Pimm, A. C., et al., Init. Repts. DSDP, 14: Washington (U.S. Govt. Printing Office), 421-485.

Savin, S. M., 1977. The history of the earth's surface temperature during the past 100 million years. Ann. Rev. Earth Planet. Sci., 5:319-355.

Schneidermann, N., 1973. Deposition of coccoliths in the compensation zone of the Atlantic Ocean. In Smith, L. A., and Hardenbol, J. (Eds.), Proceedings of the Symposium on Calcareous Nannofossils, Gulf Coast Section: Society of Economic Paleontologists and Mineralogists: Houston (SEPM), pp. 140-151.

, 1977. Selective dissolution of recent coccoliths in the Atlantic Ocean. In Ramsay, A. T. S. (Ed.), Oceanic Micropalaeontology (Vol 2): London (Academic Press), 1009-1053.

Thierstein, H. R., 1976. Mesozoic calcareous nannoplankton biostratigraphy of marine sediments. Mar. Micropaleont., 1:325-362.

1979. Paleoceanographic implications of organic carbon and carbonate distribution in Mesozoic deep sea sediments. In Talwani, M., Hay, W., and Ryan, W. B. F. (Eds.), Deep Drilling Results in the Atlantic Ocean: Continental Margins and Paleoenvironments: Washington (Am. Geophys. Union), pp. 249-274.

Tissot, B., Derod, G., and Hervin, J. P., 1979. Organic matter in Cretaceous sediments of the North Atlantic: contribution to sedimentology and paleoceanography. In Talwani, M., Hay, W., and Ryan, W. B. F. (Eds.), Deep Drilling Results in the Atlantic Ocean: Continental Margins and Paleoenvironments (Vol. 3): Washington (Am. Geophys. Union), pp. 362-374.

van Andel, Tj. H., 1975. Mesozoic/Cenozoic calcite compensation depth and the global distribution of calcareous sediments. Earth Planet. Sci. Lett., 26:187-194.

van Heck, S. E., 1979a. Bibliography and taxa of calcareous nannoplankton. INA Newsletter, 1(1):A-1-A-12, B-1-B-27.

, 1979b. Bibliography and taxa of calcareous nannoplankton. INA Newsletter, 1(2):A13-A28, B28-B42.

van Hinte, J. E., 1976. A Cretaceous time scale. Bull. Am. Assoc. Petrol. Geol., 60:498-516.

Verbeek, J. W., 1977. Calcareous nannoplankton biostratigraphy of middle and upper Cretaceous deposits in Tunesia, Southern Spain and France. Utrecht Micropaleont. Bull., 16:157.

\section{APPENDIX \\ Notes on Species}

All species of calcareous nannofossils cited in this report are listed in alphabetical order according to the species epithet. For each species, the species epithet is followed by the original author(s), by the possible subsequent author(s) who proposed the preferred combination, and by one or more references to illustrations that most closely approximate species concepts used in this study. Reference to the illustrations in this paper are added in parentheses. Remarks are added for variable species concepts, or for species difficult to identify under 
the light microscope. Some forms originally described by use of the electron microscope and some that are generally rare were grouped in genera listed at the end.

Complete synonym lists have not been prepared, and the interested reader is referred to the recent taxonomic literature, such as Black (1971, 1973, 1975), Hill (1976), and Verbeek (1977), for more-detailed taxonomic discussions. Also, not all taxonomic references are listed in the reference list. They can be found in the index and bibliography of calcareous nannoplankton by Loeblich and Tappan (1966-1971) and by van Heck (1979a, b).

Lithraphidites alatus Thierstein in Roth and Thierstein, 1972. Thierstein, 1976, pl. 4, figs. 26, 27.

Remarks. It is important that only specimens with distinctly flaring blades are included in this species, and not irregularly overgrown specimens of $L$. carniolensis. Specimens that could be assigned to Lithraphidites acutum Verbeek and Manivit (in Manivit et al., 1977, pl. 1, figs. 7, 8) were not observed.

Axopodorhabdus albianus (Black, 1967) Wind and Wise, 1977. Hill, 1976, pl. 10, fig. 22-30 (as Podorhabdus albianus).

Remarks. Strongly overgrown specimens tend to display almost completely filled central areas with a broad central cross composed of two plates that flare towards the periphery.

Vagalapilla angusta (Stover, 1966) n. comb. (Basionym: Zygolithus angustus Stover, 1966, pl. 3, figs. 14, 15, pl. 8, fig. 22)

Remarks. This species displays a cross that is not exactly aligned with the major and minor axes of the ellipse. As Verbeek (1976) has shown, this could be the ancestor of Eiffellithus turriseiffeli.

Parhabdolithus angustus (Stradner, 1963) Stradner, Adamiker, and Maresch, 1968. Stover, 1966, pl. 6, figs. 16-19. (as Parhabdolithus elongatus Stover $=$ junior subjective synonym of $P$. angustsus)

Remarks. Only specimens with a total length equal to or larger than twice its width have been included.

Parhabdolithus asper (Stradner, 1963) Manivit, 1971. Stover, 1966, pl. 3, figs. 10, 11 (as Discolithus vagus Stover, = junior subjective synonym of $P$. asper); Roth and Thierstein, 1972, pl. 7, figs. 7-17. Remarks. Specimens with and without an obvious stem are included. Transitions exist between $P$. asper and $P$. splendens, the latter being more narrowly elliptical and more abundant in the latter part of the middle Cretaceous. The two species are often combined, since they appear to have the same ecological preference and are closely related.

Watznaueria barnesae (Black, 1959) Perch-Nielsen, 1968. Stover, 1966, pl. 1, figs. 10, 11 (as Coccolithus paenepelagicus Stover $=$ junior subjective synonym of $W$. barnesae).

Watznaueria biporta Bukry, 1969. Worsley, 1971, pl. 2, figs. 24, 25 (as $W$. cynthiae Worsley $=$ junior subjective synonym of $W$. biporta Bukry).

Watznaueria britannica (Stradner, 1963) Reinhardt, 1964. Stover, 1966 , pl. 1, figs. $12-14$.

Remarks. This species has a well-developed bridge, frequently made of two elements. Specimens with a floor or a weakly birefringent bridge belong to Watznaueria communis Reinhardt, 1964.

Amphizygus brooksii Bukry, 1969. Hill, 1976. pl. 1, figs. 1-24.

Lithraphidites carniolensis Black, 1963. Hill, 1976, pl. 8, figs. 8, 9.

Cruciellipsis chiastia (Worsley, 1971) Thierstein in Roth and Thierstein, 1972, pl. 6, figs. 8-13.

Haquis circumradiatus (Stover, 1966) Roth 1978. Stover, 1966, pl. 5, figs. 2-4 (as Coccolithites circumradiatus); Hill, 1976, pl. 8, figs. 20-27 (as Markalius circumradiatus).

Vagalapilla compacta Bukry, 1969, pl. 31, figs. 10, 11.

Remarks. This species shows a characteristic clover-leaf pattern in the center under the light microscope.

Cretarhabdus conicus Bramlette and Martini, 1964. Hill, 1976, pl. 4, figs. $25-30$, pl. 13 , figs. $23,24$.
Remarks. This species is used in a very broad sense for cretarhabdids with a distinctive central cross.

Biscutum constans (Gorka, 1957) Black, 1967. Hill, 1976, pl. 1, figs. 32-37.

Remarks. This species was used for species of Biscutum that do not show a central-area structure. Specimens of Biscutum with a small central knob are assigned to Biscutum sp. cf. B. gartneri Black, 1973.

Tetrapodorhabdus coronadventis (Reinhardt, 1966) n. comb. (Basionym: Cretarhabdus coronadventis Reinhardt, 1966, p. 26, pl. 23, figs. 29, 30); Stover, 1966, pl. 5, figs. 15, 16; (as Cretarhabdus unicornis Stover $=$ junior subjective synonym of $T$. coronadventis (Reinhardt). Hill, 1976, pl. 7, figs. 1-5 (as Gephyrorhabdus coronadventis).

Remarks. This species has buttresses in the diagonal direction and a distal shield consisting of two cycles. Under the light microscope, the shields of $T$. coronadventis show higher birefringence than shields of Axopodorhabdus. The genus Gephyrorhabdus Hill, 1976 is a junior subjective synonym of Tetrapodorhabdus Black, 1973.

Cretarhabdus crenulatus Bramlette and Martini, 1964. Bramlette and Martini, 1964, pl. 2, figs. 23, 24. (Plate 1, Fig. 2).

Remarks. This species is used in a broad sense for specimens having more than eight struts in the central area and frequently showing more than one cycle of perforations between the struts. Cretarhabdus surirellus (Deflandre, 1954) Reinhardt, 1970 is a species whose structure is not known with certainty.

Prediscosphaera cretacea (Arkhangelsky, 1912) Gartner, 1968, pl. 2, figs. $10-14$, pl. 3 , figs. $10-14$, pl. 3 , figs. $8 \mathrm{a}-\mathrm{c}$, pl. 4 , figs. 19-24; pl. 6 , figs. $13-15$, pl. 9 , figs. $1-4$, pl. 12 , figs. $1 \mathrm{a}-\mathrm{-c}$, pl. 14 , figs. $20-22$, pl. 18 , fig. 8 , pl. 22 , figs. $1-3$, pl. 23 , figs. $4-6$, pl. 25 , figs. 12-14, pl. 26, fig. 2. (Plate 1, Fig. 1)

Remarks. Early forms of this species are almost circular in outline and very small. Prediscosphaera cretacea columnata (Stover, 1966) Hill, 1976 was not distinguished from $P$. cretaca cretacea, because transitions between the small circular form and the slightly larger elliptical form exist and the projections on the stem described in the former subspecies (Hill, 1976) are impossible to recognize consistently under the light microscope. Certainly a distinction of the two forms at the species level does not seem warranted.

Tetrapodorhabdus decorus (Deflandre and Fert, 1954) Wind and Wise in Wise and Wind, 1977. Bramlette and Martini, 1964, pl. 3, figs. 9-12 (as Cretarhabdus decorus).

Remarks. This species differs from $T$. coronadventis in having two small pores in the short axis and two larger pores in the long axis of the ellipse.

Cyclagelasphaera deflandrei (Manivit, 1966) Roth, 1973, pl. 26, fig. 7.

Axopodorhabdus dietzmannii (Reinhardt, 1965) Wind and Wise, 1977, Hill, 1976, pl. 10, figs. 31-33, pl. 11, figs. 1, 2, pl. 15, fig. 5 (as Podorhabdus dietzmanni).

Remarks. This species differs from A. albianus in its more robust, broader central cross and its oblong shape, with parallel sides rather than a regularly elliptical outline as observed in A. albianus.

Zygodiscus diplogrammus (Deflandre in Deflandre and Fert, 1954) Gartner, 1968. Stover, 1966, pl. 4, figs. 2-5, (as Zygolithus ponticulus $=$ junior subjective synonym of $Z$. diplogrammus); Hill, 1976, pl. 12, figs. 25-27, pl. 15, figs. 5-26. (Plate 1, Fig. 3)

Remarks. All specimens with a bridge composed of two optically continuous elements that are not optically continuous with the wall are included in this species.

Cribrosphaerella ehrenbergii (Arkhangelsky, 1912) Deflandre, 1952. Stover, 1966, pl 3, figs. 12, 13 (as Discolithus venatus = junior subjective synonym of C. ehrenbergii); Hill, 1976, pl. 5, figs. 20-32. (Plate 1, Fig. 4)

Remarks. Early forms of this species are elliptical, rather than oblong with parallel sides. The regular arrangement of crystallites and the relatively low birefringence of the shield margin are well developed in specimens as far back as zone NC10. 
Zygodiscus elegans Gartner, 1968, emend. Bukry, 1969, Roth and Thierstein, 1972, pl. 10, figs. 16-20 (as Glaukolithus elegans); Hill, 1976 , pl. 12 , figs. 23,24 , pl. 15 , figs. 27,28 .

Remarks. This species shows a double bridge that is interrupted in the middle by a central knob-like structure composed of four elements. My species concept follows the emended definition and illustrations of Bukry, 1969, as the original illustrations by Gartner, 1968 do not show sufficient ultra-structural detail, and more than one species might have been included. Zygodiscus sp. cf. Z. spiralis Bramlette and Martini, 1964 differs from Z. elegans by the presence of a slightly asymmetrical bridge with asymmetrically flaring attachment plates that are larger on opposite sides of the bridge where it attaches to the wall, and by strongly spiral extinction figures under crossed nicols.

Parhabdolithus embergeri (Noel, 1958) Stradner, 1963. Stover, 1966, pl. 2, figs. 13, 14 (as Discolithus embergeri).

Broinsonia enormis (Shumenko, 1968) Manivit, 1971. Roth and Thierstein, 1972, pl. 14, figs. 14-17, 22-29 (as Broinsonia bevieri Bukry, 1969 = junior subjective synonym of $B$. enormis).

Remarks. Under the light microscope this species of Broinsonia is difficult to separate from other species of Broinsonia, especially forms with delicate grill structures such as $Z$. dentata Bukry, and from many species belonging to the genera Acaenolithus Black and Cibricalithus Black. Specimens that lack a distinctive cross and appear to have a completely filled central area are included in this species.

Zygodiscus erectus (Deflandre in Deflandre and Fert, 1954) Manivit, 1971. Deflandre and Fert, 1954, pl. 15, figs. 14-17 (as Zygolithus erectus); Manivit, 1971, pl. 29, figs. 1-3, 5-8.

Remarks. This species is small and has a single bridge with a central knob. The grill structure that generally fills the central area between the bridge and the margin is not visible under the light microscope.

Reinhardtites fenestratus (Worsley, 1971) Thierstein, in Roth and Thierstein, 1972, pl. 8, figs. 1-12.

Lithastrinus floralis Stradner, 1962. Hill, 1976, pl. 7, figs. 21-41, pl. 8 , figs. $1-7$, pl. 14, figs. 13,14 .

Remarks. This species is used in a broad sense, and includes specimens with high and low walls that seem to grade into each other.

Tranolithus gabalus Stover, 1966, pl. 4, fig. 22.

Remarks. The single bridge is interrupted in the center, but is optically continuous with the margin.

Gaarderella granulifera Black, 1973. Part II, pl. 19, fig. 6, 10-13. (Plate 1, Fig. 5)

Remarks. This species differs from Cretarhabdus crenulatus s. ampl. in having a central area composed of irregular small blocks and a cretarhabdid margin that shows higher birefringence than Cribrosphaerella ehrenbergii; the latter species also shows a more regular arrangement of the crystallites in the central area.

Cruciplacolithus hayi Black, 1973, Part II, pl. 23, figs. 9, 10; Hill, 1976, pl. 11, figs. $27,28$.

Remarks. Small specimens with a coccolithid rim and a cross aligned in the long and short axes of the ellipse are assigned to this species.

Sollasties horticus (Stradner, Adamiker and Maresch, 1968) Čepek and Hay, 1969. Hill, 1976, pl. 11, figs. 24-26.

Remarks. The rim of the species shows low birefringence, much like Biscutum, with the exception of a narrow bright ring around the central area. The characteristic structure in the central area is best observed under the light microscope with phase optics.

Discorhabdus ignotus (Gorka, 1957) Perch-Nielsen, 1968. Hill, 1976, pl. 6, figs. 12-18. (Plate 1, Fig. 6)

Remarks. This species is sometimes referred to as $C$. rotatorius (e.g., Thierstein, 1973).
Assipetra infracretacea (Thierstein, 1973) Roth, 1973. Roth 1973, pl. 25, figs. 5, 9; Thierstein, 1973, pl. 1, figs. 1-19. (as Micula infracretacea).

Rucinolithus irregularis Thierstein in Roth and Thierstein, 1972. Thierstein, 1973, pl. 3, figs. 1-14.

Remarks. This species show dextral imbrication and has a larger number of elements (9-11) than $R$. wisei, which has always 6 elements and is sinistrally imbricate.

Stephanolithion laffittei Noel, 1956. Stover, 1966, pl. 7, figs. 25-27 (as Stephanolithion crenulatum $=$ junior subjective synonym of $S$. laffittei)

Diazomatholithus lehmani Noel, 1965. Thierstein, 1971, pl. 3, figs. 1115.

Chiastozygus litterarius (Gorka, 1957) Manivit, 1971. Thierstein, 1976, pl. 3, figs. 31, 32; Stover, 1966, pl. 4, fig. 18. (as Zygolithus cf. concinnus) (Plate 1, Fig. 7)

Remarks. Under the light microscope, this species can be distinguished from Vagalapilla stradneri by its straight arms that show symmetrical extinction figures.

Cretarhabdus loriei Gartner, 1968, pl. 24, figs. 9, 10.

Remarks. This species shows extinction of its central area by segments and is only present as typical specimens in the uppermost part of the middle Cretaceous.

Tetralithus malticus Worsley ${ }_{\star}$ 1971, pl. 2, figs. 9-11.

Cyclagelosphaera margereli Noel, 1965. Hill, 1976, pl. 14, fig. 3.

Vagalapilla matalosa (Stover, 1966) Thierstein, 1973. Stover, 1966, pl. 2, fig. 1-2 (as Coccolithus matalosus); Thierstein, 1976, pl. 3, figs. 35,36 .

Remarks. The rim of this species is eiffellithid, and the cross broadens towards the rim.

Watznaueria oblonga Bukry, 1969, pl. 11, figs. 8-10; Thierstein, 1973, pl. 5, figs. 1-12 (as Flabellites biforaminis).

Remarks. Few if any specimens assigned to this species show a distinctly flaring margin. Thus, I prefer to assign them to $W$. oblonga Bukry, 1969, rather than to Flabellites biforaminis Thierstein, 1973.

Tranolithus orionatus (Reinhardt, 1966a) Reinhardt, 1966b. Reinhart, 1966a, pl. 23, figs. 22, 31-33 (as Discolithus orionatus).

Remarks. Specimens with a broad double bridge that is optically continuous with the wall belong to this species. Etched forms sometimes assigned to $T$. exiguus Stover by other authors were included in $T$. orionatus, as suggested by Thierstein, 1974.

Watznaueria ovata Bukry, 1969. Hill, 1976, pl. 12, figs. 19-22. Remarks. This species has relatively large open central area.

Manivitella pemmatoidea (Deflandre ex Manivit, 1965) Thierstein, 1971, pl. 5, figs. 1-3.

Seribiscutum primitivum (Thierstein, 1974) Filewicz, Wind, and Wise in Wise and Wind, 1977. Thierstein, 1974, pl. 1, figs. 1-13 (as Cribroshaerella primitiva); Wise and Wind, 1977, pl. 66, figs. 4-6.

Hayesties radiatus (Worsley, 1971) Thierstein, 1976. Worsley, 1971, pl. 1, figs. 51, 52 (as Rucinolithus radiatus); Thierstein, 1976, pl. 3 , figs. 29,30 .

Remarks. This small species with about 8 bulbous arms has been assigned to Haysites atlanticus Wilcoxon, 1972 and $H$. bulbus Thierstein, 1973; both are junior subjective synonyms of $H$. radiatus.

Broinsonia signata (Noel, 1969) Noel, 1970. Roth and Thierstein, 1972, pl. 14, figs. 1-15. 
Remarks. This small Broinsonia has a distinctive cross in the center and differs from Vagalapilla stradneri in having a bright "Broinsonia-type" rim.

Corolithion signum Stradner, 1963. Hill, 1976, pl. 4, figs. 21-24, pl. 13, fig. 22.

Prediscosphaera spinosa (Bramlette and Martini, 1964) Gartner, 1968. Bramlette and Martini, 1964, pl. 2, figs. 17-20 (as Deflandrius spinosus).

Zygodiscus spiralis Bramlette and Martini, 1964. Hill, 1976, pl. 12, figs. 28-37.

Remarks. This species occurs more commonly and is more typically developed in the upper Cretaceous, but specimens with strongly spiral extinction figures found in the middle Cretaceous, especially at high latitudes, are assigned to this species. See remarks for $Z$. elegans for further discussion.

Parhabdolithus splendens (Deflandre, 1954) Noel, 1969. Roth and Thierstein, 1972, pl. 7, figs. 2-6.

Remarks. This species always has a central stem. It is more narrowly elliptical than $P$. asper, but intergradations between the two species exist.

Braarmdosphaera stenorhetha Hill, 1976, pl. 2, figs. 26-31, pl. 13, figs. 7-9.

Broinsonia stenostaurion Hill, 1976, pl. 3, figs. 13-24, pl. 13, figs. 1214.

Remarks. This unusual species of Broinsonia, first described from Texas, is found as rare specimens in the central Pacific. It is included in Broinsonia sp. on the range charts.

Tegumentum stradneri Thierstein in Roth and Thierstein, 1972. (Plate 1, Fig. 8, 9)

Remarks. Under the light microscope, this species shows asymmetrical extinction figures on its cross arms. A gray outer cycle of plates is faintly visible in well-preserved specimens.

Vagalapilla stradneri (Rood, Hay, and Barnard, 1971) Thierstein, 1973. Rood, Hay, and Barnard, 1971, pl. 1, fig. 2 (as Vekshinella stradneri); Thierstein, 1971, pl. 6, figs. 13, 14 (as Staurolithites crux).

Remarks. This species is used in a broad sense and includes all specimens of Vagalapilla with a relatively narrow central cross, with its arms aligned in the long and short axis of the ellipse. Several species possibly could be distinguished in a detailed taxonomic study.

Watznaueria supracretacea (Reinhardt, 1965) Perch-Nielsen, 1968. Hill, 1976, pl. 2, figs. 1-9.

Parhabdolithus swinnertonii (Black, 1971) Wind and Čepek, 1979. Black, 1971, pl. 34, fig. 4; Wind and Čepek, 1979, pl. 11, figs. 8-16. (Plate 1, Fig. 10)
Remarks. This species differs from $P$. splendens by the presence of a strongly inflated stem that fills almost the whole central area.

Eiffellithus trabeculatus (Gorka, 1957) Reinhardt and Gorka, 1967. Stover, 1966, pl. 2, figs. 11, 12 (as Discolithus disgretgatus = junior subjective synonym of $E$. trabeculatus) Roth and Thierstein, 1972, pl. 12, figs. 7-18; Hill, 1976, pl. 6, figs. 34-36.

Eiffellithus turriseiffeli (Deflandre and Fert, 1954) Reinhardt, 1965. Thierstein, 1976, pl. 4, figs. 15, 16.

Remarks. Specimens with a large diagonal double cross and specimens with a small cross that does not reach the wall are included in this species.

Acaenolithus spp. Black, 1973.

A number of rare small forms with a "Broinsonia-type" rim and a central cross of complex structure surmounted by a knob or stem were observed. They appear to be most similar to the genus. No attempt was made to identify these forms on the species level.

\section{Broinsonia spp.}

Species of Broinsonia not assigned to either B. enormis or $B$. signata were included in this category.

\section{Braarudosphaera spp.}

All species of Braarudosphaera and Micrantholithus.

\section{Nannoconus spp.}

The species of Nannoconus belong predominantly to the group with open central cavity ( $N$. bucheri, $N$. truitti, etc.). In the lower part of Site $463, N$. colomi is present.

\section{Rucinolithus spp.}

Irregular specimens of Rucinolithus with fewer rays than $R$. irregularis are included. There was some indication of transitions from well-preserved Discorhabdus ignotus to more highy birefringent forms with jagged outlines, and finally to forms that resemble Rucinolithus.

Scapholithus spp. Deflandre in Deflandre and Fert, 1954. Deflandre and Fert, 1954, p. 165, pl. 8, figs. 12, 16-17.

Spec. nov. A

Dart-shaped objects that seem to be composed of four blades which are possibly holococcoliths were observed in Hole 465A. These are possibly related to Lucianorhabdus compactus (Verbeeck) Prins and Sissingh, 1977, reported from the Cenomanian. Because of considerable overgrowths, its structural details are somewhat obscured, and no detailed description is given here. 


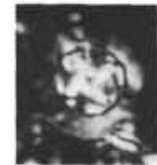

$1 \mathrm{a}$

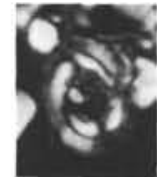

$4 a$

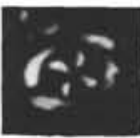

7a

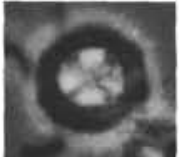

$1 b$

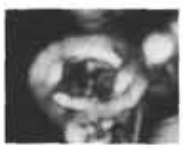

$4 b$

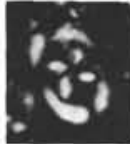

$7 b$

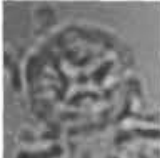

1c

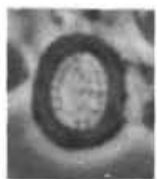

$4 c$

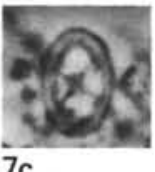

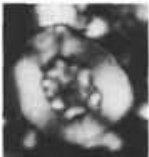

2

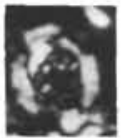

5 a

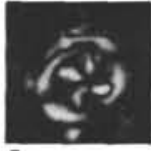

8

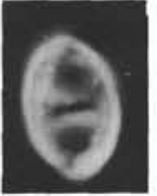

$3 a$

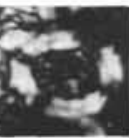

$5 b$

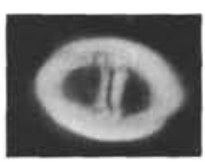

$3 \mathrm{~b}$

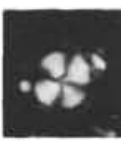

$6 a$

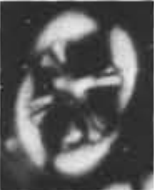

9a

$6 \mathrm{~b}$

$9 b$

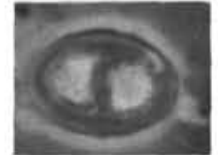

$3 c$
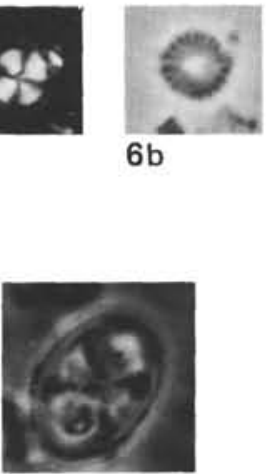

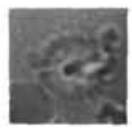

$6 \mathrm{c}$
Plate 1. Magnification $2000 \times$ except for Figure $9(2150 \times) ; \mathrm{XN}$ : cross-polarized light; $\mathrm{PH}$ : phase contrast; OL: ordinary light.

Figure 1. Prediscosphaera cretacea (Arkhangelsky) Gartner: Sample 463-43-2, $10 \mathrm{~cm}$; 1a: XN, 1b: PH, 1c: OL.

Figure 2. Cretarhabdus crenulatus Bramlette and Martini; Sample 463-43-2, $10 \mathrm{~cm}$; XN.

Figure 3. Zygodiscus diplogrammus (Deflandre in Deflandre and Fert) Gartner; Sample 258-20-1, $80 \mathrm{~cm}$ (Indian Ocean) 3a, 3b: XN; 3c: PH.

Figure 4. Cribrosphaerella ehrenbergii (Arkhangelsky) Deflandre. Sample 463-43-2, $10 \mathrm{~cm}$; 4a, 4b: XN; 4c: PH.
Figure 5. Garderella sp. cf. G. granulifera Black; Sample 465A-29-1, $133 \mathrm{~cm}$; 5a, 5b: XN.

Figure 6. Discorhabdus ignotus (Gorka) Perch-Nielsen; Sample 463-48-1, $75 \mathrm{~cm}$; 6a: XN; 6b: PH; 6c: OL.

Figure 7. Chiastozygus litterarius (Gorka) Manivit; Sample 465A27,CC; 7a, b: XN; 7c: PH.

Figure 8. Tegumentum stradneri Thierstein in Roth and Thierstein; Sample 465A-27,CC; XN.

Figure 9. Tegumentum stradneri Thierstein in Roth and Thierstein; Sample 258-20-1, $80 \mathrm{~cm}$ (Indian Ocean); 9a: XN; 9b: PH.

Figure 10. Parhabdolithus swinnertonii (Black) Wind and Čepek; Sample 465A-29-1, $133 \mathrm{~cm}$; XN. 